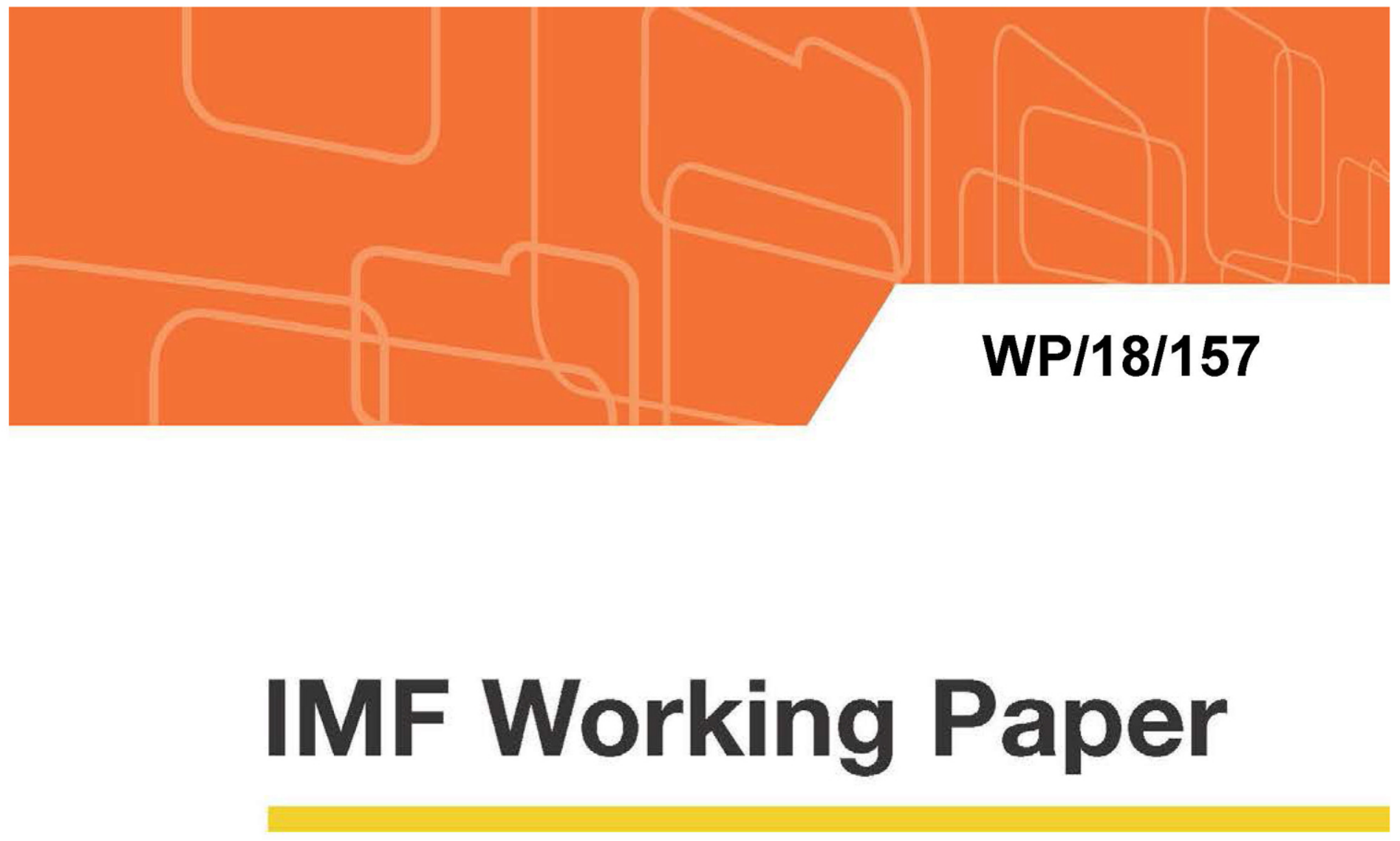

\title{
Bank Competition, Risk Taking, and their Consequences: Evidence from the U.S. Mortgage and Labor Markets
}

by Alan Xiaochen Feng

IMF Working Papers describe research in progress by the author(s) and are published to elicit comments and to encourage debate. The views expressed in IMF Working Papers are those of the author(s) and do not necessarily represent the views of the IMF, its Executive Board, or IMF management. 


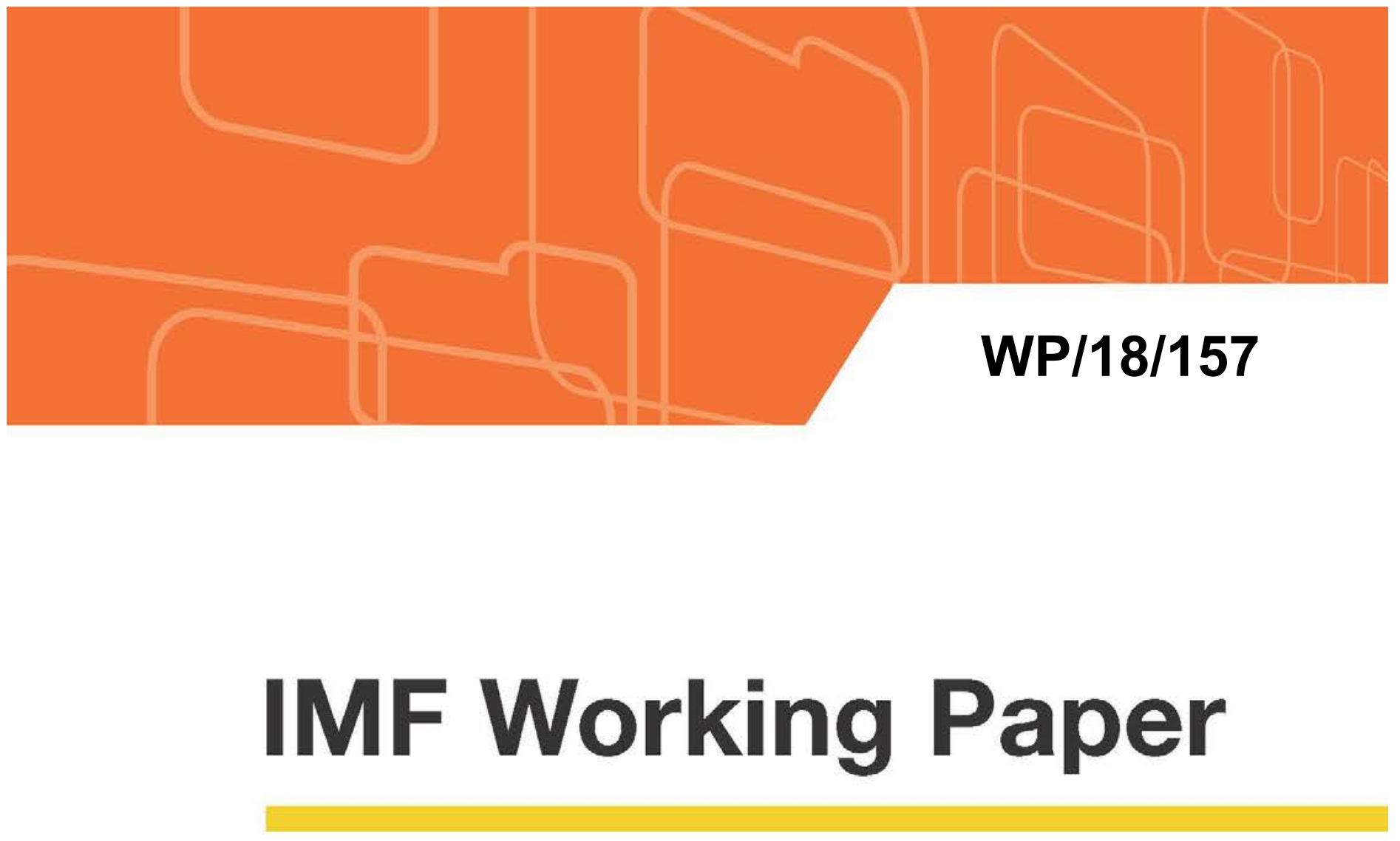

\section{Bank Competition, Risk Taking, and their Consequences: Evidence from the U.S. Mortgage and Labor Markets}

by Alan Xiaochen Feng

IMF Working Papers describe research in progress by the author(s) and are published to elicit comments and to encourage debate. The views expressed in IMF Working Papers are those of the author(s) and do not necessarily represent the views of the IMF, its Executive Board, or IMF management.

I N T E R N A T I O N A L M O N E T A R Y F U N D 


\title{
IMF Working Paper
}

Monetary and Capital Markets Department

\section{Bank Competition, Risk Taking and their Consequences: Evidence from the U.S. Mortgage and Labor Markets}

\section{Prepared by Alan Xiaochen Feng ${ }^{1}$}

\author{
Authorized for distribution by Claudio Raddatz
}

June 2018

\begin{abstract}
Bank competition can induce excessive risk taking due to risk shifting. This paper tests this hypothesis using micro-level U.S. mortgage data by exploiting the exogenous variation in local house price volatility. The paper finds that, in response to high expected house price volatility, banks in U.S. counties with a competitive mortgage market lowered lending standards by twice as much as those with concentrated markets between 2000 and 2005. Such risk taking pattern was associated with real economic outcomes during the financial crisis, including higher unemployment rates in local real sectors.
\end{abstract}

JEL Classification Numbers: G21, G28, E24

Keywords: Bank competition, risk taking, mortgage market, unemployment

Author's E-Mail Address: xfeng@imf.org

\footnotetext{
${ }^{1}$ I would like to thank Atif Mian, Markus Brunnermeier, David Sraer, Wei Xiong, Gabriel Chodorow-Reich, Martin Čihák, Stijn Claessens, Gaston Gelos, Charles Goodhart, Dong He, David Jones, James Morsink, Lev Ratnovski, Martin Saldias, Hyun Song Shin, Chris Sims, Felix Vardy, and Gang Yi for very helpful suggestions; and seminar participants at University of Minnesota, Federal Reserve Bank of Boston, National University of Singapore, Chinese University of Hong Kong, City University of New York (Baruch College), Brookings Institution, International Monetary Fund, ECB Forum on Central Banking (Sintra), Hong Kong Monetary Authority, City University of Hong Kong, Princeton University, and Midwest Finance Association Annual Conference. Any remaining errors are my own.
} 


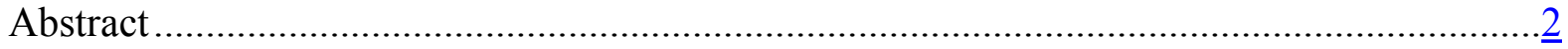

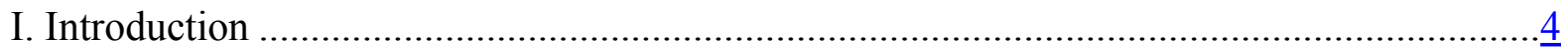

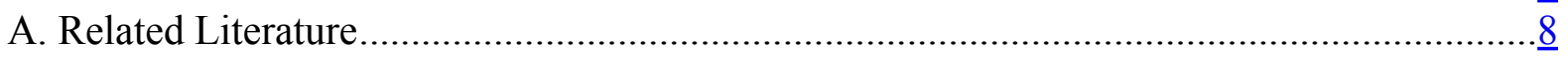

II. A Simple Theoretical Model .................................................................................

III. U.S. Mortgage Market and Data ...................................................................

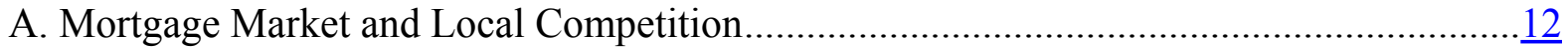

B. Mortgage and Other Economic Data..........................................................................13

IV. Empirical Analysis: Loan Risk Before the Crisis ....................................................13

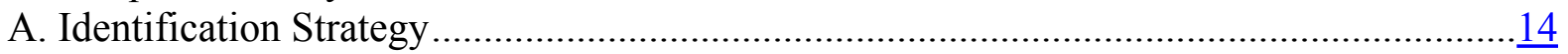

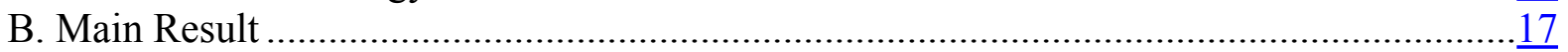

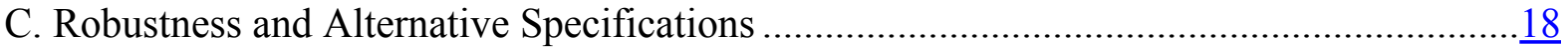

V. Real Economic Effects During and After the Crisis ............................................. 22

A. Stylized Evidence on Foreclosures and Bank Failures ................................................22

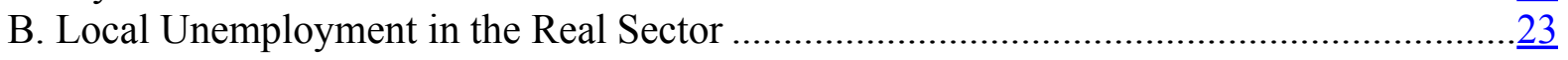

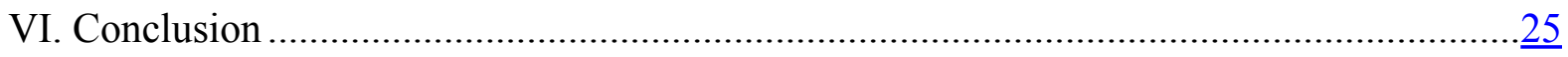

Tables

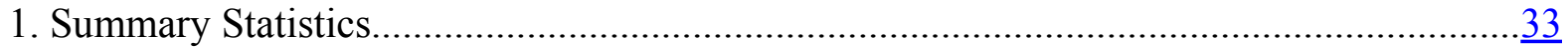

2. First Stage Regression and Exclusion Restriction .....................................................34

3. Loan-to-Income Ratio for National Banks versus Local Banks ..................................... $\frac{35}{36}$

4. Acceptance Rate for National Banks versus Local Banks............................................ $\frac{36}{37}$

5. Combining National and Local Banks ............................................................... $\frac{37}{38}$

6. Robustness Using the Herfindahl Index ...................................................................... $\frac{38}{39}$

7. Robustness Using Alternative Measures for Loan Risk and House Price Volatility............ $\underline{39}$

8. Banks in the Same County ........................................................................................ $\frac{40}{41}$

9. Bank Loan Portfolio Shift and Local Competition ..................................................... $\frac{41}{42}$

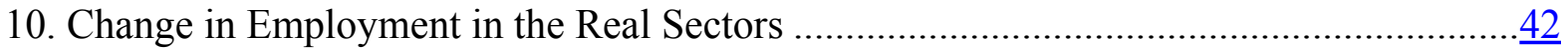

11. Change in Tradable-Sector Employment in the Real Sectors....................................... 43

Figures

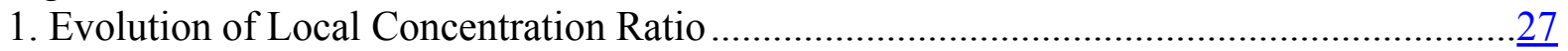

2. Historical House Price Volatility: 1982-1996 ..............................................................28

3. House Price Volatility Over the Recent Cycle and Exclusion Restriction .........................29

4. Loan-to-Income Ratio by House Price Volatility and Local Bank Competition.................. $\underline{30}$

5. Foreclosure and Bank Failure Rates During the Crisis..................................................... $\frac{31}{32}$

6. Non-Financial Employment After the Crisis …......................................................

Appendix

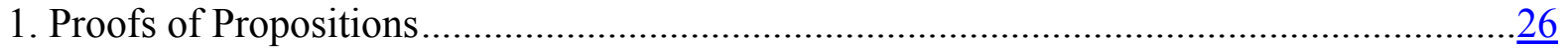

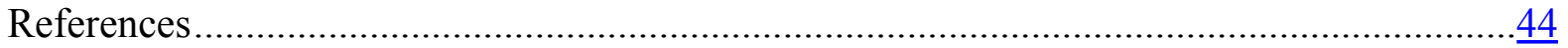




\section{INTRODUCTION}

Bank competition can induce excessive risk taking due to risk shifting. Guaranteed by limited liabilities, banks have an option-like payoff function that rewards high volatility in the asset return (Jensen and Meckling (1976)). ${ }^{2}$ Bank competition, which lowers the franchise value of the bank, makes return volatility even more attractive (Hellmann, Murdock, and Stiglitz (2000)). Testing this risk shifting hypothesis of bank competition is empirically challenging, and the impact on the real economy often remains unclear. Studying the U.S. banking system, Keeley (1990) uses banking deregulation in the 1980s as exogenous shocks to bank competition and finds that competition encouraged banks' risk taking behavior. Direct evidence on the U.S. banking sector over more recent economic cycles remains scarce, despite that scholars and policymakers, including Ben Bernanke (2007), have suggested that the competitive mortgage lending environment might have contributed to the recent financial crisis in the U.S. ${ }^{3}$ This paper tests the risk shifting hypothesis of bank competition in the context of the U.S. mortgage market during the run-up to the crisis. Our study exploits the cross-sectional differences in local mortgage-market competition and local house price volatility in the U.S. and test whether local competition had encouraged greater exposure to house price risk in banks' mortgage lending decisions.

We begin with the observation that local house price volatility can significantly affect the performance of mortgage loans, where local house price volatility is defined as the magnitude of house price movement during a boom-bust housing cycle. Particularly, it affects the amount of equity that the borrowers have in their housing assets. Given a fixed loan amount at the beginning of a housing cycle, greater house price volatility would imply that the borrowers have positive capital gains in their housing assets if the initial housing boom persists but negative equity if prices revert. This translates to a lower default probability if the boom continues but a higher default probability if a reversal happens. Indeed, local house price volatility is shown empirically to be an important determinant for mortgage loan performance. Palmer (2015) finds that over half of the subprime defaults during the crisis was due to movements in local house prices. Therefore, volatility of the house price during a housing cycle is a key risk that banks need to take into account when making mortgage lending decisions. Faced with uncertainty of the future house price, the bank can increase the loan amount issued to each borrower, which would raise its profits if the boom persists; however, raising the loan amount exposes the mortgage loan to more downside risk of the house price.

The risk shifting hypothesis implies that, in high-competition mortgage markets, banks have a stronger incentive to increase the exposure to house price volatility by lowering their lending standards. If bank equity is entirely wiped out after a housing reversal, the failed banks cease to operate and the Federal Deposit Insurance Corporation (FDIC) bears all the

\footnotetext{
${ }^{2}$ With deposit insurance, depositors do not have the incentive to monitor the riskiness of banks' assets.

3 "Some misalignment of incentives, together with a highly competitive lending environment, ... likely compromised the quality of underwriting" in the speech by Ben Bernanke on May 17, 2007, at the Federal Reserve Bank of Chicago's 43rd Annual Conference on Bank Structure and Competition, Chicago, Illinois.
} 
losses. In this paper, I map this framework into the U.S. mortgage market, using the cross-equityholders will receive the residual claim. The intuition is fairly straightforward. As each bank has limited liabilities, the residual claim of the bank's assets by equityholders or managers is a call option, i.e., the value is protected from below but has upside. Given that the value of the call option increases with volatility, as long as each bank faces a convex cost function of volatility, an optimal level of asset volatility is chosen. Banks with an at-themoney call option (i.e., in higher-competition environment) will benefit more from an increase in asset return volatility than banks with an in-the-money call option (i.e., in lowercompetition environement).

This paper maps this framework into the U.S. mortgage market, using the crosssectional variations in local house price volatility and mortgage market competition. In particular, the study exploits the exogenous variation in local house price volatility and study the differences in lending decisions made by banks in high- and low-competition local markets. The paper tests the risk shifting hypothesis that banks in high-competition markets are more willing to be exposed to volatility in the house price by lowering their lending standards (such as increasing the loan-to-income ratio) compared to those in low-competition markets. If the risk shifting hypothesis is true, one would expect the relationship between lending standards and house price volatility to be stronger when bank competition is high. The key regressor in the empirical specification is the interaction term between house price volatility and bank competition while the dependent variable is the change in mortgage lending standards.

Identification of the cross-sectional variation in local house price volatility utilizes a feature of the U.S. housing market that local house prices are largely determined by local geography during each housing cycle. Glaeser, Gyourko, and Saiz (2008) find that housing supply elasticity, a land-topology based measured constructed by Saiz (2010) using satellite data, is a key determinant for local house price volatility during each past housing cycle. They show that supply-inelastic areas tend to have volatile house price swings during each housing cycle than supply-elastic areas as housing supply cannot immediately adjust to reduce price fluctuations. In this paper, the Saiz (2010) housing supply elasticity is used to measure to instrument for the historical local house price volatility between 1982 and 1996, which naturally formed the prior for banks entering the 2000s housing cycle. We then verify that the 2000s housing cycle followed exactly the pattern predicted by housing supply elasticity. We further show that empirical results are robust to treating the realized house price volatility as exogenous. As the analysis is cross-sectional, any nation-wide shocks would not affect the conclusions documented in this paper, as long as the local effects of these shocks are not systematically related to local competition. The focus on the interaction term in the empirical specification has additional advantages that help the identification, as any confounding factors that jointly determine house price volatility and lending standards would not bias the estimate of the interaction term, as long as these factors do not systematically vary with local bank competition. In Section IV, by utilizing information in the county-bank pairs, the paper also examines banks' lending standards with the inclusion of county fixed effects as well as the portolio shifts of bank mortgages to caputre the extensitve margin of risk taking. More detailed discussions are included in Section IV.C. 
Local mortgage market competition is measured at the U.S. county level using the Concentration Ratio (CR) and the Herfindahl index as of 2000, and these measures have been shown in the literature to be able to capture the level of local competition in U.S. mortgage markets (e.g., Scharfstein and Sunderam (2016)). ${ }^{4}$ This local measure of mortgage market competition captures the fact that households in the U.S. primarily shop locally for mortgages and other financial services (e.g., Amel, Kennickell, and Moore (2008)). To identify the effect of local competition, the paper distinguishes banks that are local and more subject to local competition from national banks. This is because local competition would only induce the risk shifting incentive for local banks, but not for national banks, which are exposed to the average level of competition across all local markets they operate in. Therefore, the predictions from the risk shifting hypothesis of local competition described above would be mostly for lending decisions made by local banks but not for national banks, where national banks are defined as operating in more than five or ten U.S. states. The distinction between these two types of banks allows for the identification of banks' risk shifting incentive through local competition.

This paper finds strong evidence consistent with the risk shifting hypothesis. We find that, faced with higher house price volatility, banks in high-competition markets lowered mortgage lending standards (e.g., loan-to-income ratio and acceptance rate) by twice as much as those in low-competition markets between 2000 and 2005. Mortgage loans in these markets were made more vulnerable to house price risk by banks in these high-competition markets. Further distinguishing the lending decisions of local banks from national banks, this paper finds that the effect of local competition was only present for loans issued by local banks and did not exist for national banks, a result consistent with the risk shifting hypothesis of local competition. This result turns down alternative hypotheses that do not have incentive distortions associated with local competition. Results are similar when excluding securitized loans as well as controlling for a wide range of other local factors, such as local employment and wage growth; local employment in financial and construction sectors; and the shares of investment homes and refinancing loans. Similar results are obtained using the loan-to-value ratio and the fraction of high-interest mortgage loans as alternative measures for loan risk. ${ }^{5}$

As loans were made more sensitive to the downside risk of house prices, house price volatility was more damaging for high-competition markets than for low-competition markets during the crisis. This paper finds that the lower quality of mortgage loans in high competition markets indeed was associated with worse realization of risks when the house price came down, resulting in higher rates of foreclosures and bank failures. Furthermore, there was also the credit supply effect that harmed local non-financial sector employment

\footnotetext{
${ }^{4}$ I constructed these indices based on the HMDA database. In the main specification, all kinds of financial institutions are included in the construction of these indices. Results are similar when measuring competition only among commercial banks. The CR is measured as the combined market share of the top ten lenders in each county. The Herfindahl index is the sum of market share squared of all lenders in a county. A higher value of the CR or the Herfindahl index is associated with lower bank competition.

${ }^{5}$ The average loan-to-value ratio in each county is calculated based on the Monthly Interest Rate Survey (MIRS) by aggregating zip-code level data. Fraction of high-interest mortgage loans is calculated based on the HMDA database.
} 
through the impaired local financial sector. In high-competition local markets, a larger drop in the employment rate between 2007 and 2009 by 1.5 percent occurred for one standarddeviation increase in the local house price volatility; in contrast, such relationship did not exist in low-competition markets. This effect was especially strong for smaller-sized firms. Note that the difference in this relationship between high-competition and low-competition markets reflect the effects on employment from the (credit) supply side. Based on this new empirical strategy in this study, these effects are in addition to the demand-side channels emphasized by Mian and Sufi (2014) through households' balance sheet. To account for potential demand-side factors highlighted in the literature, the empirical results are shown to be robust to the inclusion of local demand-side factors as control variables, such as the local debt-to-income ratio used by Mian and Sufi (2014), as well as the complete exclusion of nontradable sectors that depend on local demand. ${ }^{6}{ }^{7}$

This paper provides new evidence on the risk shifting incentive associated with bank competition. It is among the first studies that exploit an exogenous cross-sectional variation in asset risk to examine this relationship and test in the context of the U.S. mortgage market over the past housing cycle. The paper employs a novel empirical strategy to examine the credit supply channel on real outcomes during and after the crisis through the risk taking pattern prior to the crisis. Disentangling the effect of loan supply shock on real outcomes is often challenging, and this study provides a strategy that could overcome this difficulty. It offers insights in understanding the macro-financial linkages between the risk taking incentive in the financial sector and real sector activities such as employment.

Note that while this paper looks at the welfare costs of the risk shifting agency problem associated with bank competition, it by no means argues that bank competition does not bring efficiency benefits. Higher local market competition lowers the interest margin that banks charge customers and increases the pass-through of monetary policy (e.g., Scharfstein and Sunderam, 2016). Higher banking sector competition is also found in other studies to improve banking sector efficiency and stability (Schaeck, Cihak and Wolfe, 2009; Schaeck and Cihak, 2014; Allen, Carletti, and Marquez, 2011). This paper only examines the relationship between bank competition and risk taking against house price volatility in the specific U.S. mortgage market during a specific time period between 2000 and 2005.

The rest of this paper is organized as follows. Section I.A. provides a summary of the related literature in this area of research. Section II demonstrates an illustrative model, which generates empirical predications. Section III describes the data sources, followed by Section IV showing the identification strategy and empirical results on loan risk before the crisis. In

\footnotetext{
${ }^{6}$ To account for potential demand-side factors highlighted in the literature, the empirical results are shown to be robust to the inclusion of local demand side factors as control variables, such as the local debt-to-income ratio used by Mian and Sufi (2014), as well as the complete exclusion of non-tradable sectors that depend on local demand.

7 This paper also shows robustness of results by including tradable sectors only and by controlling for local debt-to-income ratio, a proxy for local demand. Mian and Sufi (2014) categorize sectors into tradable and nontradable ones based on the geographic concentration of these sectors. They show that the rise in nontradable sector employment between 2007 and 2009 was strongly associated with high local household indebtedness, while tradable sector employment was little affected by local demand.
} 
Section IV.C, a few alternative measures and empirical specifications are used to show robustness of results. Section V displays analysis on the consequences during and after the crisis and Section VI concludes this paper.

\section{A. Related Literature}

This paper is related to multiple strands of literature. First, it is related to the bankcompetition-instability relationship due to agency problems. Jensen and Meckling (1976) identify the risk shifting agency problem between equityholders and debtholders of a firm, which can be especially severe for banks as bank liabilities are often explicitly or implicitly guaranteed by the government. Keeley (1990) points out that the risk taking incentive of a bank is associated with its charter value, which is the expected future profits that accrue to the bank's owner, as higher charter value deters banks from investing in risky projects. In his framework, greater market power generates higher profits and charter value, reducing risk taking by the bank. Allen and Gale (2004) and Hellman, Murdock, and Stiglitz (2000) consider a setting where competition among banks lowers the return on the safe asset and therefore it encourages risk taking. Competition in the lending market has drawn particular attention in recent decades (e.g., Boyd and De Nicoló (2005)) as as changes in funding costs in recent years no longer predict bank lending behaviors due to the nation-wide decline in funding costs (e.g., Loutskina and Strahan (2009). ${ }^{8}$

On the empirical evidence of the risk shifting hypothesis, Keeley (1990) finds that the rise in bank risk in the 1980s (which later resulted in the S\&L crisis) was associated with the increased bank competition during bank deregulation period in the 1970s and 1980s. On evidence of the risk-shifting agency problem of banks, using quasi-natural experiments, Landier, Sraer, and Thesmar (2015) and Gan (2004) find that exogenous declines in the franchise value of banks can encourage risk taking. On the international scope, using panel data over 1980-1997 for 70 countries, Beck, Demirgüç-Kunt, and Levine (2004) find a negative correlation between the frequency of banking crises and banking sector concentration, although they also show that fewer regulatory restrictions on banks, which could result in a more competitive banking sector, also improves banking stability. Schaeck, Čihák, and Wolfe (2009) discuss the differences in bank competition and concentration, while in this paper competition is narrowly defined at the local level. Jimenez, Lopez, and Saurina (2013) document the potential non-linear relationship between bank competitition and risk taking. Becker and Ivashina (2015) document similar risk shifting behavior for insurance companies, which are similarly guaranteed by state guaranty funds.

The second related strand of literature focuses on the effect of financial disruptions on real economic activities. Kiyotaki and Moore (1997) and Brunnermeier and Sannikov (2014) point out that financial shocks can be amplified and can greatly affect the real economy when

\footnotetext{
${ }^{8}$ Boyd and De Nicoló (2005) argue that bank competition in the asset market and deposit market can have different effects if corporate borrowers face the same risk shifting agency problem as banks. In the context of the U.S. mortgage market studied in this paper, such agency problems on the borrower side are not present. because mortgage borrowers do not face the same investment decisions as corporates once the loans are granted. See also Petersen and Rajan (1995) and Claessens and Laeven (2004) for more discussions.
} 
firms have financial constraints. ${ }^{9}$ Some recent studies look at how financial factors can affect employment especially after the recent crisis. Chodorow-Reich (2014) finds that adverse financial shocks to banks implied worse employment outcomes for firms borrowing from the troubled banks. Mian and Sufi (2008, 2010, and 2014) highlight the importance of household balance sheet in explaining the dramatic rise in unemployment after the crisis through the demand channel.

This paper is linked to the literature examining mortgage lending in the years preceding the recent crisis and the subsequent defaults during the crisis. One closely related study is Palmer (2014) who shows that most defaults of recently issued subprime mortgages during the crisis were driven by dramatic fluctuations in the house price, as opposed to the decline in borrower quality. ${ }^{10}$ My study complements Palmer (2014) by studying bank credit supply factors due to competitive pressure that drove the risk taking behavior against house price volatility. Our study also complements the literature explaining the aggregate risk taking behaviors by banks in the time series. There are studies from the time-series perspective that emphasize the agency problems (e.g., Allen and Gale (2004)) and other studies that bring in behavioral components which encourage optimism (e.g., Cheng, Raina, and Xiong (2014)) while this paper uses a cross-section empirical design.

\section{A Simple Theoretical Model}

Consider banks that borrow from deposits and invest in a risky asset. The value of the underlying risky asset net of deposits $S$ is a geometric Brownian motion under a risk-neutral probability:

$$
\frac{\mathrm{d} S}{S}=\mu d t+\sigma \mathrm{d} B
$$

where $B$ is a Brownian motion under the risk-neutral probability and $\mu d t$ is the drift term. We assume that $\mu$ is a constant, as well as a risk-free rate $r$. For a mortgage issuing bank, the performance of the bank's mortgage portfolio is subject to an aggregate house price risk $\mathrm{d} B$. We assume that the volatility $\sigma\left(l, \sigma^{h p}\right)$ is a function of the lending risk $l$ and the underlying house price volatility $\sigma^{h p}$. Here lending risk $l$ can represent the loan-to-income ratio that each bank grants to borrowers. A higher loan-to-income ratio for borrowers would make the loan performance more sensitive to the house price risk, as it increases the likelihood of the borrowers having negative equity in the home. Therefore, a higher $l$ increases the volatility term, i.e., $\sigma^{\prime}\left(l ; \sigma^{h p}\right)>0$. For simplicity, we assume $\sigma\left(l ; \sigma^{h p}\right)=l \sigma^{h p}$. The risky asset follows the following geometric Brownian motion:

\footnotetext{
${ }^{9}$ See also Peek and Rosengren (1997, 2000), Gan (2007), Gertler and Gilchrist (1994), Khwaja and Mian (2008).

${ }^{10}$ See also Adelino, Schoar, and Severino (2014), Keys, Mukherjee, Seru, and Vig (2009) for disucssions on mortgage loan origination and default risk.
} 


$$
\frac{\mathrm{d} S}{S}=\mu d t+\sigma(l) \mathrm{d} B
$$

Each bank maximizes the value of bank at a pre-determined time $T$ subject to a cost function $M(l)$ and limited liabilities. Increasing loan risk involves some costs $M(l)$ where $M^{\prime}>0$ and $M^{\prime \prime}>0$. This functional captures the fact that lowering loan risk increases the pool of loan application which requires additional operational cost to screen applicants. Under these assumptions, the value of the bank can be viewed as a European call option with strike price $K$ equal to the residual value of a failed bank and additional operational costs $M(l)$. Note that the drift of the Brownian motion is not a function of loan risk in the absence of arbitrage opportunities.

Therefore, the maximization problem of the bank at time $t=0$ is

$$
\max _{l} \mathrm{E}_{0} \max \left(K, S_{T}\right)-M(l)
$$

where $S_{T}$ is the terminal value of the European option at maturity. Under standard assumptions, the value of the call option is given by the following Black-Scholes equation

$$
\mathrm{E}_{0} \max \left(K, S_{T}\right)=C(S, t)=S_{0} n\left(d_{1}\right)-e^{-r T} K n\left(d_{2}\right)
$$

where $n(\cdot)$ is the probability density function of the standard normal distribution, $d_{1}=\frac{\log \frac{S_{0}}{K}+\left(r+\frac{1}{2} \sigma^{2}\right) T}{\sigma \sqrt{T}}$ and $d_{2}=d_{1}-\sigma \sqrt{T}{ }^{11}$

The degree of bank competition is captured by the ratio $\frac{S_{0}}{K}$. In a highly competitive environment, $\frac{S_{0}}{K}$ is smaller, as banks have lower profitability initially. Denote the optimal level of loan risk by $l^{*}$. The first-order condition of the bank's maximization problem is given by

$$
\frac{\partial C}{\partial l^{*}}-M^{\prime}\left(l^{*}\right)=0
$$

Assumption: $\log \left(\frac{S_{0}}{K}\right)+r T>\frac{1}{2} \sigma(l)^{2} T$ for all $l$.

The assumption above ensures that the call option is sufficiently in-the-money at time 0 for all banks. This is a realistic assumption as most operating banks have positive franchise value at the time of conducting lending business.

Proposition 1. Banks increase lending risk $l$ when volatility of house price $\sigma^{h p}$ goes up exogenously, i.e., $\frac{\partial l^{*}}{\partial \sigma^{h p}}>0$.

\footnotetext{
${ }^{11}$ We assume no arbitrage conditions regarding banks' value.
} 
Proof: See Appendix.

Proposition 2. When volatility of house price $\sigma^{h p}$ goes up exogenously, banks in a highercompetition environment increase lending risk $l$ more strongly, i.e., $\frac{\partial^{2} l^{*}}{\partial \sigma^{h p} \partial S_{0}}<0$.

Proof: See Appendix.

Prediction 1a. Banks increase the loan-to-income ratio of loans when house price volatility is high. This response diminishes as local market competition decreases.

Prediction 1b. Local competition affects the lending decisions made by local banks and should not have an effect on those made by national banks.

Predictions $1 \mathrm{a}$ and $1 \mathrm{~b}$ represent banks risk taking measured by ex-ante measures such as loan-to-income ratios of mortgage loans. Proposition 1a is a direct derivative of the above propositions. Because competition is measured locally in this paper, a stronger version of this prediction uses this feature and has some further implications. Prediction $1 \mathrm{~b}$ suggests that local competition only captures the franchise value of local banks but not that of national banks.

Prediction 2a. During the crisis, higher house price volatily implies greater mortgage losses and potentially greater bank failures; this relationship diminishes as local market competition decreases.

Prediction 2b. For local employment in non-financial sectors after the crisis, higher house price volatility would also be damaging and especially so where local bank competition is high.

Predictions $2 \mathrm{a}$ and $2 \mathrm{~b}$ measure the amount of damages ex-post. If banks indeed took more risk, the amount of losses incurred would depend on house price volatility and local competition, through their lending decisions affecting loan risk during the boom. Prediction 2 suggests that the strength of banks' balance sheet during the crisis follows the competitionrisk taking pattern. One can further investigate if the impaired balance sheet had implications on the real economy through reduced credit supply. The prediction below looks at these implications in the local non-financial sectors after the crisis. 


\section{U.S. Mortgage Market ANd DAta}

The U.S. mortgage market has some characteristics that make the empirical analysis possible. Data availability at the loan application level allows for accurate measurement of loan risk and the identification of local competition effect. Below is some description of the characteristics of the U.S. mortgage market as well as the main data sources used in the analysis.

\section{A. Mortgage Market and Local Competition}

In this paper, mortgage markets are assumed to be local. Specifically, we assume that competition among banks in the local mortgage market is closely linked to the market power that affects lending decisions and that county-level measures of bank competition are good proxies for the level of competition local banks are faced with. ${ }^{12}$ In the main specification, the study includes all loans recorded by HMDA and issued by banks, credit unions, and independent mortgage companies. This is largely accurate for the mortgage market in the U.S. as studies have consistently found that most borrowers in the U.S. only shop mortgages locally. For example, using data from the Survey of Consumer Finances, Amel, Kennickell, and Moore (2008) find that more than half of U.S. households obtained mortgage loans from an institution that was less than 25 miles away from home. In fact, they find that the median household lived within four miles of their primary financial institution and that 25 percent of households obtained mortgages just from this primary institution. Scharfstein and Sunderam (2016) find that measures of mortgage market competition at the U.S. county level, such as the Herfindahl index and CR, capture the market power for banks conducting business in the local area. There are various other studies showing that the average borrowers in the U.S. only considered two loans while shopping for mortgages (Lacko and Pappalardo (2010)) and that local advertisement affects the borrowing decisions of homebuyers (Gurun, Matvos, and Seru (2016)), all suggesting that competition at the local level matters for the U.S. mortgage market.

To measure the level of local competition, the paper follow studies in the literature of mortgage markets (e.g., Scharfstein and Sunderam (2016)) by constructing the U.S. countylevel CR and the Herfindahl index (HHI), both measured as of 2000. The CR is the total market share of the top ten lenders in the county. The HHI is defined as the sum of market share squared for all lenders in a county. A higher value of the CR or the HHI indicates greater concentration and less competition in the local market. Figure 1 plots the evolution of the CR at the U.S. county level from 1995 to 2005 . The four lines represent the four quartiles of all 3,185 U.S. counties by their CR as of $1995 .{ }^{13}$ One can see that, while local mortgage markets have become increasingly competitive over time, the relative ranking of the $\mathrm{CR}$ has

\footnotetext{
${ }^{12}$ In the main specification, I include loans issued by banks, credit unions, and other thrift institutions. I control for the fraction of thrift institutions and commercial banks in the local mortgage market. Results are robust if only commercial banks are considered. For more discussions on different types of financial institutions, see Dagher and $\mathrm{Fu}(2017)$.

${ }^{13}$ There are 3185 counties with data coverage in the HMDA database during the 1995-2005 period.
} 
remained unchanged. As a result, cross-sectional variations in the level of competition are not significantly affected by the year in which they are measured.

\section{B. Mortgage and Other Economic Data}

Loan-level mortgage data are based on the HMDA database, which records almost all mortgage loan applications between 2000 and 2005. For each loan application in a given year, the following information is recorded: the loan amount, the income of the applicant, the type of the loan (e.g., home purchase or refinance), the county location, whether the loan was approved, a lender identifier, the type of the lender (e.g., commercial bank or thrift), and whether the loan was later sold to other financial institutions, among other characteristics. Lenders instead of mortgage brokers are recorded in the database.

The paper uses the HMDA data to construct the loan-to-income (LTI) ratio of each loan approved as well as the acceptance rate of all loans. Higher loan-to-income ratios and acceptance rates signal riskier mortgage loans. We construct these measures both at the county level and at the lender level using the lender identifier. We also construct other county-level measures as my control variables, such as the share of investment homes, the share of thrift institutions, the share of securitized loans, the share of refinancing loans, and among others. The paper also complements the loan-to-income ratio and acceptance rate as the riskiness of loans by the county-level loan-to-value (LTV) ratio at the county level using data from MIRS.

House price data are from S\&P/Case-Shiller Home Price Index as well as the House Price Index provided by Zillow. Availability of these data traces back to the 1980s. Local geography data are based on the Saiz (2010) Housing Supply Elasticity (HSE) measure, which ranges from 0 to 5 . We transfrom HSE into an inverse measure for housing supply inelasticity, defined as $(5-H S E) / 5$, so that the inelasticity measure lies between 0 and 1 . Therefore, higher housing supply inelasticity is generally associated with larger house price volatility.

Local employment data are from County Business Patterns (CBP) database published by the U.S. Census Bureau. The database has total employment and wage information at the sector level and for each establishment size group. It is available at the annual frequency for each U.S. county. Employment variables are used both as controls in the pre-crisis risk taking analysis and as the post-crisis outcome variable as a consequence of risk taking. Other data sources include FDIC for failed banks, Quarterly Census of Employment and Wages (QCEW) from the U.S. Census Bureau for county-level population estimates and wage rates.

\section{Empirical Analysis: LoAn Risk Before The CRISIS}

The empirical analysis follows closely the theoretical predictions shown above. Consider that at the beginning of a housing cycle the house price patterns across regions start to deviate from each other. In some areas, the house price is expected to be more volatile than in other areas: the house price is expected to either rise or fall by a larger magnitude. The lending decisions by local banks become non-trivial in areas where the house price is volatile: raising the loan-to-income ratio would generate additional profits if the house price rises going 
forward, but it would incur significant losses if the house price falls. The conjecture posed in this situation is that local competitive pressure matters. That is, banks lowered their lending standards in response to the volatility in future house prices if the lending market has high competition. The paper focuses on the 2000-2011 housing cycle and study the changes in lending decisions at the beginning of the cycle between 2000 and 2005 as my dependent variable. The independent variables include the expected local house price volatility and its interaction term with local bank competition. The coefficient of interest in this analysis is the interaction term for which the hypothesis is that, when house price volatility became high, banks lowered their mortgage lending standards only when local competition is high. In other words, higher local competition encouraged banks to expose their mortgage returns to the local house price risk.

The risk shifting hypothesis outlined in the previous sections has even stronger empirical predictions. Intuitively, banks that have a large loan portfolio across the country should not have the incentive to shift risk in a certain local mortgage market even if local competition is high. On the contrary, local competition should matter more for smaller local and regional banks that are more subject to local market conditions. Therefore, for each county, we distinguish lending decisions made by national banks (i.e., operating in more than five or ten states) from those made by local and regional banks (i.e., operating in fewer than five or ten states). The risk shifting hypothesis of local bank competition would simply suggest that the coefficient for the interaction term is significant only for lending decisions made by local and regional banks, but should be insignificant for national banks as local competition does not matter for them.

\section{A. Identification Strategy}

The empirical analysis requires the identification of expected local house price volatility. ${ }^{14}$ Features of the U.S. housing market make this identification possible. Over the past decades, the U.S. housing market experienced several boom-bust cycles among which the 1982-1996 housing cycle and the recent 2000-2011 cycle were the most notable ones. One important common characteristic of each past housing cycle is the differences in the magnitude of the cycle across U.S. cities. For example, during the 1982-1996 cycle, some U.S. metropolitan areas experienced dramatic real house price swings where the peak-trough distance is over twenty percent while other regions had flat real prices for the whole period. Glaeser, Gyourko, and Saiz (2008) find that a key determinant explaining these different patterns in the local house price is local geography. In areas where land supply is limited to build new houses, house prices tend to have larger volatility during a housing cycle. These price patterns associated with local geography repeated during the recent 2000-2011 housing cycle.

In this paper, we use HSE, a land-topology-based measure constructed by Saiz (2010) using satellite data, to instrument for the volatility of the local house price during a housing cycle. This Housing Supply Elasticity measure captures the degree of natural land constraints that

\footnotetext{
${ }^{14}$ House price volatility is endogenous. Favara and Imbs (2015), for example, shows that credit supply has an effect on house prices.
} 
limit the building of residential houses. A lower HSE measure indicates that supply is unable to ramp up easily in response to rises in the price, making house prices volatile during a housing cycle. In this paper, we use this HSE measure to instrument for historical local house price volatility (1982-1996), which naturally formed the prior for lending banks entering the 2000 s housing cycle. The study confirms that the 2000s housing cycle followed exactly the same pattern predicted by the HSE measure. In 
Figure 2 and Figure 3, we plot the local house price patterns in different U.S. metropolitan areas. One can see that areas with relatively inelastic housing supply (i.e., lower HSE) experienced clearly larger price swings over both the 1982-1996 and the 2000-2011 cycles.

To show convincingly that this HSE measure affects the house price pattern only through the limitation of land supply, we plot the number of new building permits issued between 2000 and 2005 in U.S. Core-Based Statistical Areas (CBSAs) by their average HSE measure. We can see that areas with inelastic housing supply indeed had the lowest growth in new housing permits whereas elastic-supply areas had the highest growth. This evidence further confirms that HSE affects the volatility of house prices through the limitation on land supply. On the contrary, we also plot the evolution of local real wage rates across regions by their HSE measure in Figure 3. The growth patterns in the real wage across regions were almost identical. This suggests that the HSE measure is uncorrelated with demand factors that may also affect mortgage loan quality, the dependent variable in the empirical analysis.

Note that, because the coefficient of interest is the interaction term between house price volatility and bank competition, the results shown in this paper still hold even if the instrumental variable HSE is correlated with certain variables other than house price volatiltiy that also affect loan lending decisions. As long as these correlated variables do not have systematically different effects on loan risk across regions with different bank competition levels, the estimate of the coefficient on the interaction term is still valid. To fully absorb county-level characteristics, in the robuestness section, an alternative specification examines the bank-county pairs and includes county fixed effects. Empirical results are qualitatively similar.

Table 2 shows the first-stage regression results. In column (1), house price volatility during the 1982-1996 cycle, defined as the peak-trough distance in percentage, is regressed against housing supply inelasticity, a normalized inverse transformation of HSE. ${ }^{15}$ One can see that inelastic-supply areas had large housing price volatility. Similar results hold for the 2000-2011 housing cycle, as demonstrated in columns (2)-(3). In both cases, the $t$-statistics are greater than 3 in the first stage. On the contrary, column (4) shows the regression results of wage rate growth on HSE where the coefficient is estimated to be statistically insignificant from zero. This shows that factors that affect loan risk through the demand side are not correlated with the instrumental variable.

It is also important to identify the effect of local competition on risk shifting. To do that, the paper makes use of the fact that national banks that operate across many mortgage markets should not be affected by local competition whereas local banks may have the incentive to shift risk if competition in the market they operate is high. In other words, local competition should not induce any risk shifting incentive for national banks. Therefore, for each county, we label each loan as either local bank or national banks loans where national banks are

\footnotetext{
${ }^{15}$ Housing supply inelasticity is defined as $(5-H S E) / 5$.
} 
defined as operating in more than ten states as of $2000 .{ }^{16}$ Then we consider the change in lending standards for local banks and national banks separately. If competition indeed induces risk shifting incentives, then we should see that local competition has an effect on how lending standards respond to house price volatiltiy only for loans issued by local banks.

\section{B. Main Result}

The main empirical model in this study is given below

$$
\Delta \text { LoanRisk }_{i}^{2000-2005}=\beta_{0}+\beta_{1} \text { HPVol }_{i}+\beta_{2} \text { HPVol }_{i} \times \text { Conc }_{i}+\beta_{3} \text { Conc }_{i}+\gamma X_{i}+\epsilon_{i}
$$

where $\Delta$ LoanRisk $k_{i}^{2000-2005}$ is the 2000-2005 change in loan risk (e.g., loan-to-income ratio, acceptance rate) for county $i, \mathrm{HPVol}_{i}$ is the expected local house price volatility, Conc $_{i}$ is the CR or Herfindahl index for county $i$ as of 2000, and $X_{i}$ is a list of control variables including both mortgage market characteristics and real economic variables. The coefficient of interest is $\beta_{2}$ on the interaction term. A negative estimate for $\beta_{2}$ would suggest that loan risk became higher when faced with house price uncertainty only in competitive mortgage markets. Furthermore, for each county, we also construct the loan risk measures for the lending decisions made by national banks and local/regional banks separately, where national banks are defined as operating in ten or more U.S. states and local banks are those that operate in fewer than ten states. We estimate the coefficients $\beta_{2}$ for these two groups of lenders and test whether they are statistically different.

Results based on loan-to-income ratios as the risk measure are reported in Table 3. Columns (1)-(3) present regression results based on lending decisions made by local banks. One can see that the coefficient on the interactin term between house price volatility and CR is negative and statistically significant. This result holds with the inclusion of various control variables for either characteristics of the mortgage market or the real economy, or both. In contrast, column (4) presents results based on lending decisions made by national banks. A clear contrast is that the coefficient on the interaction term between house price volatility and $\mathrm{CR}$ is statistically insignificant, which suggests that the lending decisions in response to house price volatility made by national banks did not depend on local market competition at all. This is consistent with the risk shifting hypothesis of bank competition because national banks by definition have access to multiple mortgage markets and should have no incentives to shift risk because of local competition. Columns (5)-(6) include lending decisions made by both national and local banks and test if the coefficients on the interaction terms are statistically different by including a triple interaction term of house price volatility, CR, and the indicator variable for national banks. One can see that lending decisions made by national banks indeed have a significantly less negative coefficient on the interaction term since the coefficient on the triple interaction term appears strongly positive.

\footnotetext{
${ }^{16}$ National banks are defined as those that issued mortgage loans in more than ten states and the total number of loans exceeded 10,000 reported in HMDA database as of 2000.
} 
An alternative measure for lending decisions is the acceptance rate, i.e., one minus the denial rate. The higher the acceptance rate, the more likely that the lender approves the loan. ${ }^{17}$ Table 4 presents the regression results in a similar format as for the loan-to-income ratio. In columns (1)-(3), the dependent variable is the change in the acceptance rate for local banks only. One can see that the coefficient on the interaction term is negative and is statistically significant. In comparison, the coefficient becomes statistically insignificant for the acceptance rate by national banks, as demonstrated in column (4). Combining these two groups shows that the coefficients on the interaction term are statistically different between national banks and local banks, a result similar to the case of loan-to-income ratio.

One would expect that combining lending decisions made by national and local banks would yield a result in between national and local banks. Results in Table 5 confirm this prediction and show that the coefficient on the interaction term between house price volatility and CR is negative for both the change and the logged change in the loan-to-income ratio as well as for the change in the acceptance rate. In terms of the magnitude, one standard-deviation increase in house price volatility in the cross section (s.d. $=0.05$ ) is associated with 0.20 percent (or 10 percent) increase in the loan-to-income ratio and 1.5 percentage point increase in the acceptance rate in counties with high competition (i.e., quintile of counties with CR below 0.45). Compared to counties with low competition (i.e., quintile of counties with CR above $0.65)$, this magnitude of the change lending standards doubles that for mortgage markets with low competition.

Figure 4 illustrates this result graphically. The upper panel of Figure 4 plots the percentage change in the loan-to-income ratio from 1998 to 2005. The blue and red solid lines are inelastic-supply and elastic-supply areas with a competitive mortgage market, respectively, while the orange and green dashed lines are inelastic-supply and elastic-supply areas with a concentrated mortgage market. One can see that there is a much larger difference between the two solid lines than between the two dashed line, suggesting that facing house price uncertainty, lending standards were lowered only in high-competition markets. The lower panel plots the absolute change in the loan-to-income ratio in the 789 U.S. counties in the sample from 2000 to 2005 where similar conclusions can be drawn.

\section{Robustness and Alternative Specifications}

In this section, we examine the relationship between local competition and risk taking of banks using alternative measures and alternative empirical specifications. Alternative empirical specifications tackle two issues. First, based on bank-county pair information, county fixed effects are included to absorb all time-invariant factors at the county level. Second, in addition to the lending standards, we also look at the shift of portfolio for banks to capture the extensive margin of risk taking.

\footnotetext{
${ }^{17}$ The acceptance rate, however, also incorporate demand-side information. Increasing number of low-quality applicants can mechanically reduce the acceptance rate in which case the lender did not change their lending standards.
} 


\section{Alternative County-level Measures}

Both the independent and dependent variables can be measured differently. Local market competition can be alternatively measured by the HHI, following Scharfstein and Sunderam (2016). The Herfindahl index is defined as the sum of market share squared in each county as of 2000 at the beginning of the housing cycle. Similar to the CR, a lower Herfindahl index indicates greater competition in the lending market. Using the Herfindahl index as of 1995 well before the housing cycle yields similar empirical results.

Table 6 reports the regression results using the Herfindahl index at the county level as of 2000. Columns (1)-(3) show the estimates of coefficients where the dependent variable is the percentage change in the loan-to-income ratio between 2000 and 2005. In column (1) only lending decisions made by local banks are considered whereas column (2) only includes decisions made by national banks. Similar to the results using the CR, one can see that the interaction term between house price volatility and the Herfindahl index is strongly signficiant and negative for local banks but not for national banks. The difference between these two groups is also statistically signficant as shown in column (3) where both groups of banks are included. Columns (4)-(6) report similar regression results where the dependent variable is the change in the acceptance rate of mortage loans. Again, we see a similar result that the effect of local competition encouraged lowering lending standards by local banks but not those by national banks. The difference between the two groups is statistically significant.

Besides alternative measures of bank competition, robustness checks are conducted using alternative measures for loan risk and house price volatility. Alternative measures for loan risk include the interest rate and the LTV ratio. The interest rate charged on mortgage loans often capture another dimension of creditworthiness of borrowers, complementary to the loan-to-income ratio and acceptance rate, which measure the "quantity" dimensions of loan quality. The loan-to-value ratio is another measure that takes into account the collateral value of the house in addition to borrower quality. To measure high-interest loans, our study uses the share of mortgage loans as of 2005 that have an interest spread higher than the threshold that the Home Mortgage Disclosure Act (HMDA) requires to report after 2004. Loan-tovalue information is based on survey data from MIRS available at the zip-code level. We weight each zip code according to their population to construct the county level data. In addition to these alternative measures for loan risk, we also use the realized house price volatility between 2000 and 2001 treating it as exogenous to show robustness of results. Using the realized house price volatility would correct any correlation between the error terms in the regressions and the interaction term between the instrumented house price volatility and $\mathrm{CR}$.

Table 7 reports the results for these robustness checks. Columns (1)-(2) show coefficient estimates for share of high-spread loans originated and columns (3)-(4) show estimates for

percentage change in the loan-to-value ratio. Consistent with results we have seen previously, the coefficient on the interaction term between house price volatility and CR is negative and statistically significant. Columns (5)-(6) report the simple OLS regression results treating the realized house price volatility between 2000 and 2011 as exogenous. One can see that, 
similar to results in the previous sections, local banks had a strongly negative coefficient on the interaction term between house price volatility and CR while the coefficient is statistically insignificant and economically negligible for lending decisions made by national banks.

\section{Controlling for County Fixed Effects}

To address the potential endogeneity concerns of county-level bank competition, our study examines how two banks in the same county changed their lending behavior differently. Consider two similar multi-branch banks $A$ and $B$ lending in county $C$. Suppose that bank A mainly operates in relatively competitive mortgage markets while bank B has business in more concentrated markets. According to the risk shifting hypothesis above, from 2000 to 2005, bank $A$ would raise the loan-to-income ratio more than bank $B$ in the same county $C$. Moreover, if county $\mathrm{C}$ has inelastic housing supply (i.e., high house price volatility), the difference between the change in lending standards of banks A and B would be the largest. We conduct the following analysis.

$$
\Delta L T I_{b, c}^{00-05}=\alpha_{c}+\beta_{1} w H H I_{b}+\beta_{2} w_{H H I} \times \operatorname{Elas}_{c}+\beta_{3} X_{b}+\epsilon_{b, c}
$$

where $\Delta L T I_{b, c}^{00-05}$ is the 2000-2005 percentage point change in the average loan-to-income ratios issued by bank $b$ in county $c, \alpha_{c}$ is county fixed effects, $w H H I_{b}$ is the value-weighted average of the Herfindahl indexes for bank $b$ across counties as of 2000, Elas $s_{c}$ is the housing supply elasticity of county $c$, and $X_{b}$ includes bank controls such as size, type, and total loan amounts. In this analysis, to have more comparable banks in the sample, we restrict my sample to bank-county pairs where the county represents at least 1 percent and at most 50 percent of the bank's total mortgage portfolio as these banks.

Table 8 shows the empirical estimates. In column (1), we regress the change in LTI for the bank on its weighted average of HHI alone. We can see a slightly negative correlation but it is statistically insignificant. In columns (2) and (3), the interaction term between the weighted average HHI with the housing supply elasticity of the county is included. Column (2) shows that $\beta_{1}<0$ and $\beta_{2}>0$ and both estimates are statistically significant. This suggests that, for counties with very inelastic housing supply, a higher competition level (i.e., lower HHI) for the bank is associated with a larger increase in LTI from 2000 to 2005; for elastic-supply counties, this difference was much weaker. Columns (3) shows similar results with the inclusion of bank controls. In columns (4)-(6), we repeat the same exercise but measure bank competition in a county by CR instead of the Herfindahl index. One can see that all these exercises yield similar estimates.

\section{Bank-level Loan Portfolio Changes}

Raising the loan-to-income ratio is one dimension that banks could increase their load on housing risk. Another dimension is that multi-branch banks might adjust their loan issuance through their branches. Increasing loan issuance aggressively in inelastic areas increases the 
correlation of the return of their mortgage portfolio with the aggregate housing shock. Banks mainly operating in competitive mortgage markets would be more willing to issue loans to inelastic areas through branches as to increase the correlation of loan performance to the house price shock.

First, for each bank, we compute the weighted average of the Herfindahl index (or CR) of counties for the bank as of 2000, denoted as $w H H I_{b}$. we compute the value-weighted average of elasticities of counties in which the bank had mortgage lending activities in 2000 and in 2005. The difference in elasticities $\Delta \operatorname{Elas}_{b}^{00-05}$ measures the change in loan portfolio between these years. The change in average elasticity consists of two parts: some mechanical change caused by natural loan growth in some areas and the intentional part that banks adjusted. The mechanical change takes into account the situation that some counties in the bank's portfolio experienced growth in population and total loan issuance, which results in the change in the bank's average elasticity. To correct for this difference, we compute AverageChang $e_{b}^{00-05}$, defined as the counterfactual change if each bank maintained the same market shares in all counties between 2000 and 2005. Subtracting this counterfactual amount from the actual change measures the intentional change in bank $b$ 's portfolio chioce across counties.

Specifically, the follow model is considered

$$
\Delta \text { Elas }_{b}^{00-05}-\text { AverageChang } e_{b}^{00-05}=\beta_{0}+\beta_{1} w_{H H} I_{b}+\beta_{2} X_{b}+\epsilon_{b}
$$

where $X_{b}$ includes bank controls such as bank size, total mortgage issuance, and bank type. Note that the housing supply elasticity measure is not available for all counties. Our study focuses on banks which the availability of the measure covers at least 70 percent of their total mortgage portfolio as of 2000. Table 9 reports the regression results. Column (1) reports the regression result of the change in elasticity in relation to the average Herfindahl for the bank. The coefficient is positive and significant, suggesting that banks faced with low local concentration HHI (i.e., high local competition) intentionally increased loan issuance in inelastic counties. In column (2), we restrict the sample by retaining banks that had the elasticity measure covering over 99 percent of their mortgage portfolio and find a similar estimate. Column (3) repeats the exercise by including bank controls, such as bank size, securitized share, and bank type. In columns (4)-(5), headquarter state FEs are included. The coefficient on the weighted average HHI of the bank remains positive and statistically significant, especially when states that have a large number of banks. In columns (6)-(7), we use the weighted average CR instead of Herfindahl index for each bank as of 2000. One can see that higher bank-level local competition predicted greater shifts towards inelastic areas. 


\section{Real Economic Effects During ANd After the Crisis}

Assessing the welfare implications of such risk taking involves two parts. First, the excessive risk-taking behavior due to the risk-shifting agency problem harms the interests of debt holder of the banks in favor of their equity holders. Deposit insurance would then transfer these damages from depositors to government guaranty funds. Second, as banks play an important role in the real economy as the financial intermediary, losses incurred by banks due to their risky mortgage lending behavior would damages the real economy through the credit supply channel. Intuitively, banks may reduce their lending to the corporate sector when the risk in their mortgage portfolio materializes. On these two dimensions of economic effects of risk taking, our study looks at foreclosures and bank failures to capture the degree of the direct effects of risk taking in the mortgage market and banks' financial health, and focus on the local unemployment rate in the real sectors to examine the spillover effects to the real economy.

\section{A. Stylized Evidence on Foreclosures and Bank Failures}

When lending standards were lowered in areas where house price volatility is high, the fall in the house price would be more damaging to the mortgages from the issuing bank's

perspective. For example, when the loan-to-income ratio is raised in areas where house prices are volatile, the decline in the house price would likely leave borrowers with negative equity in the house. From the issuing bank's perspective, this would reduce the return from these mortgages as borrowers are likely to default. Therefore, one direct variable that measures the degree of mortgage damages to lenders is the foreclosure rate at the county level.

Another related variable is the bank failure rate. If banks issued riskier loans given house price volatility going forward, the decline in the house price would also harm the financial health of these banks. In fact, the risk shifting hypothesis implicitly anchors on the assumption that banks in high-competition markets may be willing to take on more risk because their liabilities are guaranteed in the case of failures. Therefore, we look at the rate of bank failures across regions and examine whether more bank failures are associated with greater house price declines only in relatively competitive markets.

This paper shows some stylized facts on the foreclosure rate at the county level between 2007Q1 and 2008Q2 where data are available. In the upper panel of Figure 5, we plot the foreclosure rate against housing supply elasticity which proxies for house price volatility for high-competition and low-competition counties separately. There is a negative correlation between the foreclosure rate and housing supply elasticity, meaning that inelastic-supply areas that had larger house price volatility experienced greater foreclosure rates. This relationship does not exist for low-competition markets. The difference between highcompetition and low-competition counties is statistically significant. These stylized facts on the foreclosure rate indicate that mortgage loans seemed to perform worse when house price declines only in high-competition markets.

In the lower panel of Figure 5, we present some stylized evidence on the bank failure rate. Between 2008Q1 and 2014Q3, nearly 500 U.S. banks failed as reported by the FDIC. we group geographic regions by their housing supply elasticity and investigate where the headquarters of these failed banks were located. The bank failure rate is calculated by 
dividing the number of failed bank in each region by the total number of banks that had lending activities as of 2005. One can see in the left figure of the lower panel of Figure 5 that the bank failure rate in high-competition mortgage markets is strongly associated with housing supply elasticity, a proxy for house price volatility. In the most inelastic-supply areas (i.e., HSE falls between 0 and 1), 3 percent of banks that had lending activities in these areas failed during this time period. The bank failure rate drops as HSE increases (i.e., as house price volatility falls). The right figure plots the relationship between the bank failure rate and house price volatility in low-competition regions where we can see that the negative relationship becomes much weaker. Note that while this evidence is consistent with the hypothesis that house price declines are more damaging in high-competition markets than in low-competition markets, one caveat is that bank failures can result from businesses other than their mortgage portfolios. This stylized evidence on the bank failure rate primarily is to highlight the existence and importance of the risk shifting incentive for banks.

\section{B. Local Unemployment in the Real Sector}

Banks play an important role in the real economy as financial intermediaries. Therefore, losses incurred by banks due to excessive risk taking could have implications on the real economy as well possibly through the reduction of credit. This would further imply that borrowing firms could suffer. In this section, we study the spillover effects to the real sector associated with the competition-risk taking relationship. In particular, we look at the change in employment in the local non-financial sectors after the crisis between 2007 and 2009. We focus on employment by non-financial firms, especially smaller-sized firms, both because it has important welfare and policy implications and because it is shown that non-financial firm employment could experience significant losses when the lending banks suffer liquidity shortages and capital constraints (Chodorow-Reich, 2014).

To formally test the spillover effects to the real economy, our study looks at the change in non-financial sector employment between 2007 and 2009. We intentionally exclude the financial sector, real estate, and construction-related sectors. The empirical specification has the similar independent variables as in the previous sections, including the instrumented house price volatility, Herfindahl index and their interaction term. The coefficient of interest is once again this interaction term. A positive coefficient on the interaction term would suggest that in low-competition markets employment drops less in response to large house price movements. In this analysis, we drop the 5 percent of counties with the lowest competition. The reason for dropping these counties is that these low-competition counties generally have smaller population and fewer number of firms, and as a result, the County CBP database often reports noise flags for these counties or masks the information due to confidentiality.

Table 10 reports the regression results. Columns (1)-(2) report the regression results based on all counties in the sample, while in columns (3)-(9) are based on the sample after dropping counties with the lowest 5 percent competition level. We can see in columns (3)-(5) that the coefficient on the interaction term between bank competition and house price volatility is strongly positive whether or not one controls for other local variables. This suggests that between 2007 and 2009 employment was more strongly affected by house price 
volatility in high-competition counties than in low-competition counties. In terms of the magnitude, one standard deviation increases in house price volatility (s.d. $=0.05)$ implies a drop-in employment by 1.5 percent in high-competition counties; this relationship diminishes to zero in low-competition counties. Note in column (4) that controlling for the local debt-toincome ratio does not change the result significantly, suggesting that the interaction term with bank competition indeed capture the loss of employment due to disruption in local credit supply.

Additional tests are conducted to confirm the credit supply channel of employment. Gertler and Gilchrist (1994) and Chodorow-Reich (2014) highlight that adverse credit shocks tend to have a larger impact on smaller-sized firms than on large firms. Therefore, for each county, we calculate the change in employment of firms by their establishement sizes, namely, below 20 employees, between 20 and 50 employees, between 50 and 100 employees, between 100 and 500 employees, and above 500 employees. Columns (6)-(9) in Table 10 show the regression result. Note that $\mathrm{CBP}$ database typically does not accurately report firms with over 500 employees for confidentiality, therefore results on firms with 500 employees or more are not reported. One can see that as the number of employee increases, the coefficient on the interaction term between bank competition and house price volatility loses statistical significance. For small-sized firms with fewer than 50 employees, the effect of bank competition is the strongest. This is consistent with studies in the literature that adverse credit supply shocks hurt smaller-sized firms more strongly.

Another way to avoid any local confounding factors on the demand side is to focus on non-financial sectors that produce goods being demanded nationally. In their seminal work, Mian and Sufi (2014) categorize non-financial sectors into tradable and nontradable sectors. ${ }^{18}$ Tradable sectors such as manufactering of machinery, electronics and apparal produce goods that are demanded nationally, whereas nontradable sectors such as restaurants, supermarkets and other local services are demanded only locally. We follow their definition of tradable and nontradable sectors and examine the change in employment in tradable sectors only. ${ }^{19}$ Doing so would make sure that any correlation between local factors and employment is from local supply.

Table 11 reports the empirical results. Columns (1)-(4) show the regression results of the percentage change in tradable employment between 2007 and 2009 on house price volatility and its interaction with bank competition. One can see that the interaction term shows up as statistically signiciant and positive. Notice that local control variables such as debt-to-income ratio as of 2006 and percentage change in popoluation are not correlated with the change in tradable employment, unlike the regression of tradable and nontradable sectors combined. This confirms that the change in tradable employment indeed was driven by local credit supply channels. Columns (5)-(6) consider further the change in tradable employment

\footnotetext{
${ }^{18}$ Mian and Sufi (2014) define tradable sectors as those that produce goods in relatively concentrated geographic areas and nontradable sectors as those that have high dispersion. They define sectors that have a high Herfindahl index of geographic distribution as tradable sectors.

${ }^{19}$ In this exercise, I do not include counties that do not have tradable sectors or have very small tradable sectors (below 3 percent of population), according to the definition by Mian and Sufi (2014).
} 
between 2003 and 2007 as the placebo. We can see that house price volatility and its interaction term with bank competition are statistically insignificant, which suggests that the results during the 2007-2009 period are not mechanically linked to county characteristics.

\section{Conclusion}

The risk shifting incentive identified by Jensen and Meckling (1976) can induce excessive risk taking by banks in a competitive environment (Hellmann, Murdock, and Stiglitz (2000)). This paper tests this risk shifting hypothesis of competition in the U.S. mortgage market between 2000 and 2005. Our study exploits a natural exogenous variation of local house price volatility in the cross section of U.S. cities and counties, one of the most important sources of risk for mortgage returns. This paper finds that banks in high-competition markets lowered their lending standards (e.g., raising the loan-to-income ratio and acceptance rate) in anticipation of high house price volatility while those in low-competition markets did not, an indication consistent with the risk shifting hypothesis.

This paper also examines the real economic consequences of this risk taking pattern through the credit supply channel. In particular, it studies the change in local employment in non-financail sectors at the beginning of the Great Recession. We find that between 2007 and 2009 non-financial sector employment in high competition markets lost 1.5 percent for one standard deviation increase in local house price volatility, while this relationship was insignificant for low-competition markets. This exercise identifies a credit-supply channel, in addition to the demand channel shown in Mian and Sufi (2014), that contributed to the rise in non-financial sector unemployment during the Great Recession.

The analysis in this study shows the importance of banks' risk taking incentive due to competition prior to the recent crisis. It helps deepen the understanding of why the financial sector had accumulated so much mortgage risk despite that an reverting house price would lead to massive mortgage defaults (e.g., Palmer (2015)). When studying the impact on the real economy such as non-financial sector employment, this risk taking pattern can also be used to identify the credit supply channel of bank lending. This analysis offers a possible strategy to disentangle the supply and demand effects of bank lending on real economic activities. 


\section{Appendix 1. Proofs of Propositions}

\section{A. Proof of Proposition 1}

Proof: First, the Vega of the European call option is given by

$$
\frac{\partial C}{\partial \sigma}=K e^{-r T} n\left(d_{2}\right) \sqrt{T}
$$

where $n$ is the density function of the standard normal distribution and $d_{2}=\frac{\log \frac{S_{0}}{K}+\left(r+\frac{1}{2} \sigma^{2}\right) T}{\sigma \sqrt{T}}-$ $\sigma \sqrt{T}$. Note that Vega of a European call option is positive. Applying the chain rule to the first order condition of the bank's maximization problem gives

$$
\frac{\partial C}{\partial \sigma} \sigma^{h p}-M^{\prime}\left(l^{*}\right)=0
$$

Since $M^{\prime \prime}>0, \frac{\partial C}{\partial \sigma}>0$, the solution $l^{*}$ increases with $\sigma^{h p}$, i.e., $\frac{\partial l^{*}}{\partial \sigma^{h p}}>0$.

\section{B. Proof of Proposition 2}

Proof: The Vanna of the European call option is given by

$$
\frac{\partial^{2} C}{\partial \sigma \partial S_{0}}=\frac{v}{S}\left[1-\frac{d_{1}}{\sigma \sqrt{T}}\right]
$$

where $v$ is the Vega of the call option and $d_{2}=\frac{\log \frac{S_{0}}{K}+\left(r+\frac{1}{2} \sigma^{2}\right) T}{\sigma \sqrt{T}}$. Note that Vega of a European call option is positive. Under Assumption 1, it is easy to verify that $\frac{\partial^{2} C}{\partial \sigma \partial S_{0}}<0$. The intuition is that the Vega of the call option is higher when the option is in-the-money compared to when it is at-the money. The first-order condition again is given by

$$
\frac{\partial C}{\partial \sigma} \sigma^{h p}-M^{\prime}\left(l^{*}\right)=0
$$

Since $M^{\prime \prime}>0, \frac{\partial^{2} C}{\partial \sigma \partial S_{0}}<0, \frac{\partial C}{\partial \sigma}>0$, the solution $l^{*}$ increases with $\sigma^{h p}$ but the sensitivity declines with $S_{0}$, i.e., $\frac{\partial^{2} l^{*}}{\partial \sigma^{h p} \partial S_{0}}<0$. 


\section{Figure 1. Evolution of Local Concentration Ratio}

This figure plots the evolution of the CR (top-10) from 1995 to 2005 at the county level where the CR (top-10) is defined as the total market share of the top ten mortgage lenders in the county. The four lines represents the four quartiles of counties by their CR as of 1995 and the counties are tracked over time. The CR measure has declined over time nationally, suggesting increasingly competitive local mortgage markets in the U.S.

However, the relative ranking of CR across U.S. counties has remained the same over the years.

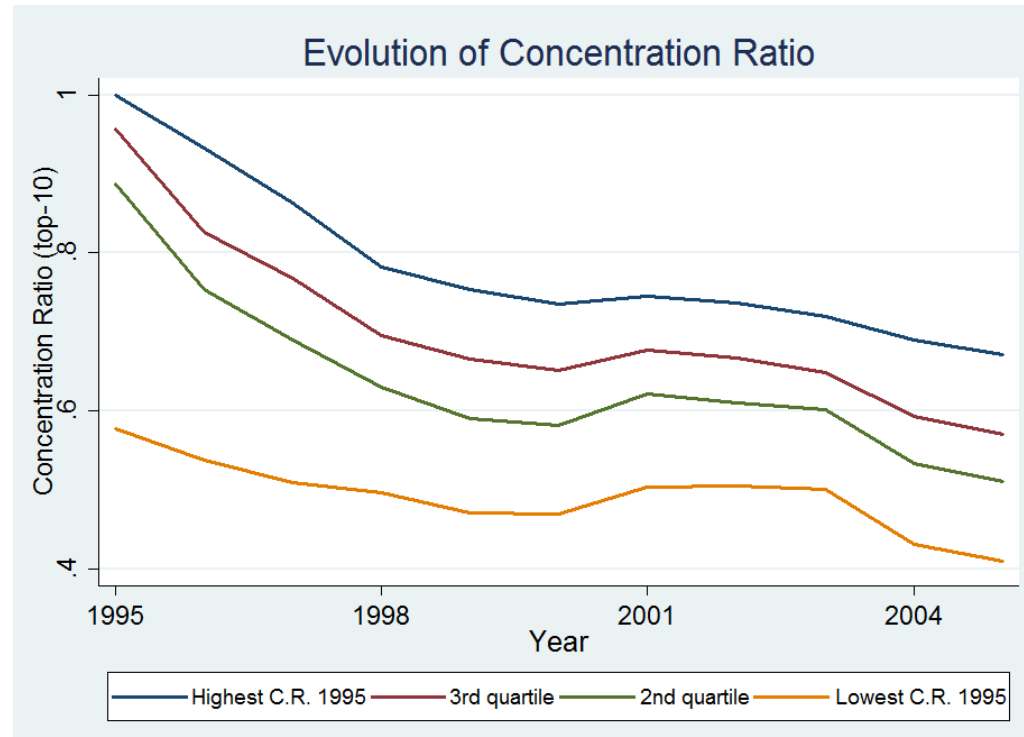


Figure 2. Historical House Price Volatility: 1982-1996

This figure plots the quintiles of the detrended S\&P/Case-Shiller Home Price Index from 1982 to 1996 at the CBSA level according to the local house price elasticity (Saiz (2010)). Since inflation was high during this period, a national trend is subtracted for all groups. We can see that the most inelastic areas (the black and rose-red lines) experienced much larger house price volatility than the elastic areas (the red, orange and green lines), consistent with the findings in Glaeser, Gyourko and Saiz (2008).

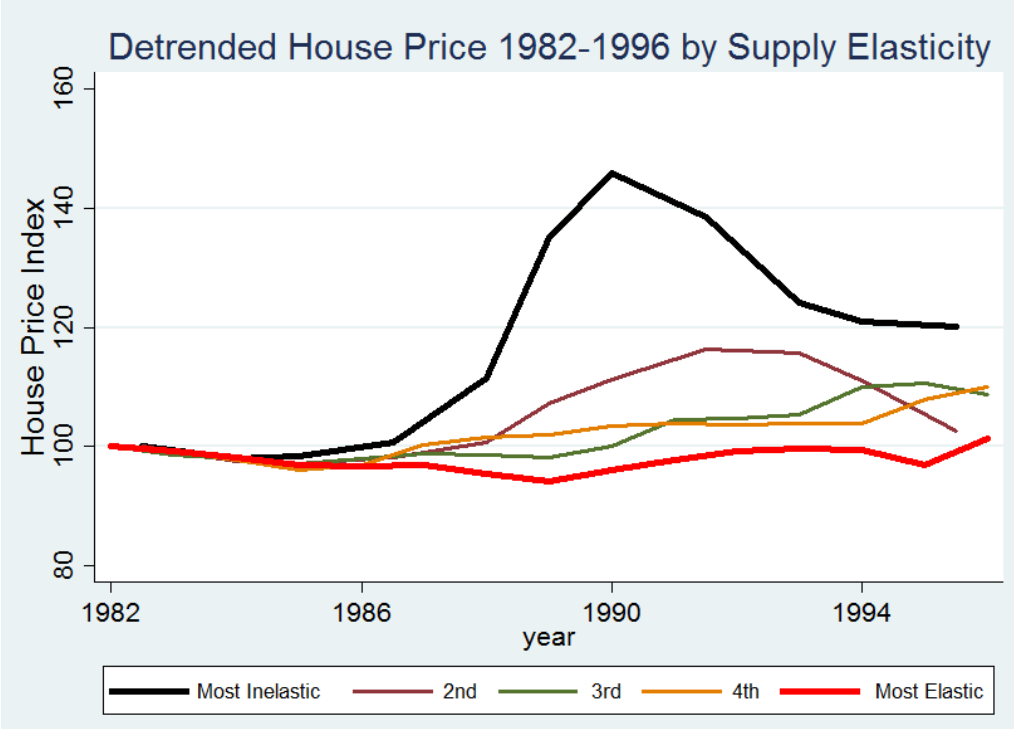


Figure 3. House Price Volatility Over the Recent Cycle and Exclusion Restriction

The upper panel in this figure plots the S\&P/Case-Shiller Home Price Index for quintiles of CBSA areas by their housing supply elasticity (Saiz (2010)). The middle panel plots the number of new building permits from 2000 to 2005 for these quintiles by housing supply elasticity. The lower panel plots the growth of real wages in these quintiles by housing supply elasticity.
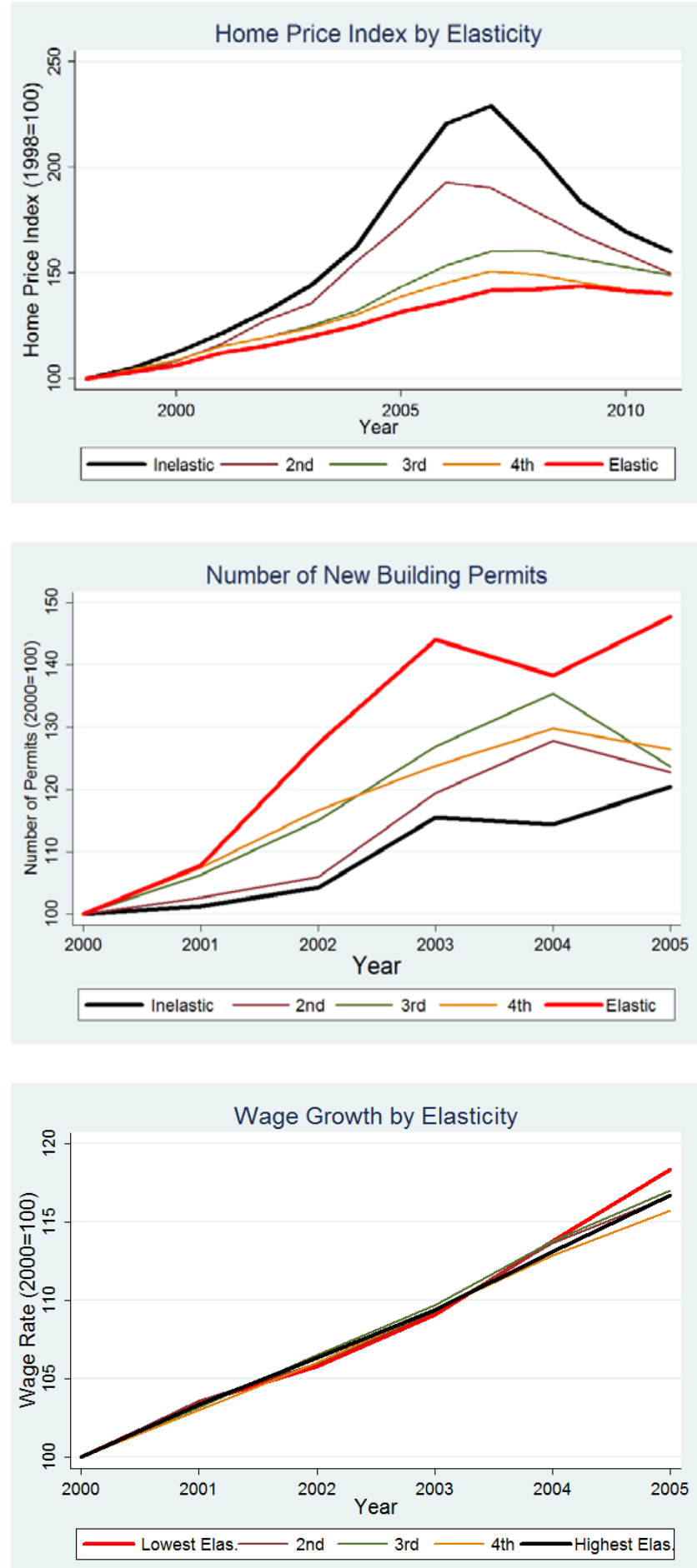


\section{Figure 4. Loan-to-Income Ratio by House Price Volatility and Local Bank Competition}

The upper panel in this figure plots the evolution (percentage change) of the loan-to-income ratio in the 789 U.S. counties in the sample from 1998 to 2005 . The blue and red solid lines are inelastic-supply and elastic-supply areas with a competitive mortgage market, respectively. The orange and green dashed lines are inelastic-supply and elastic-supply areas with a concentrated mortgage market. The lower panel plots the same graph with the absolute change in the loan-to-income ratio in the 789 U.S. counties in the sample from 2000 to 2005.
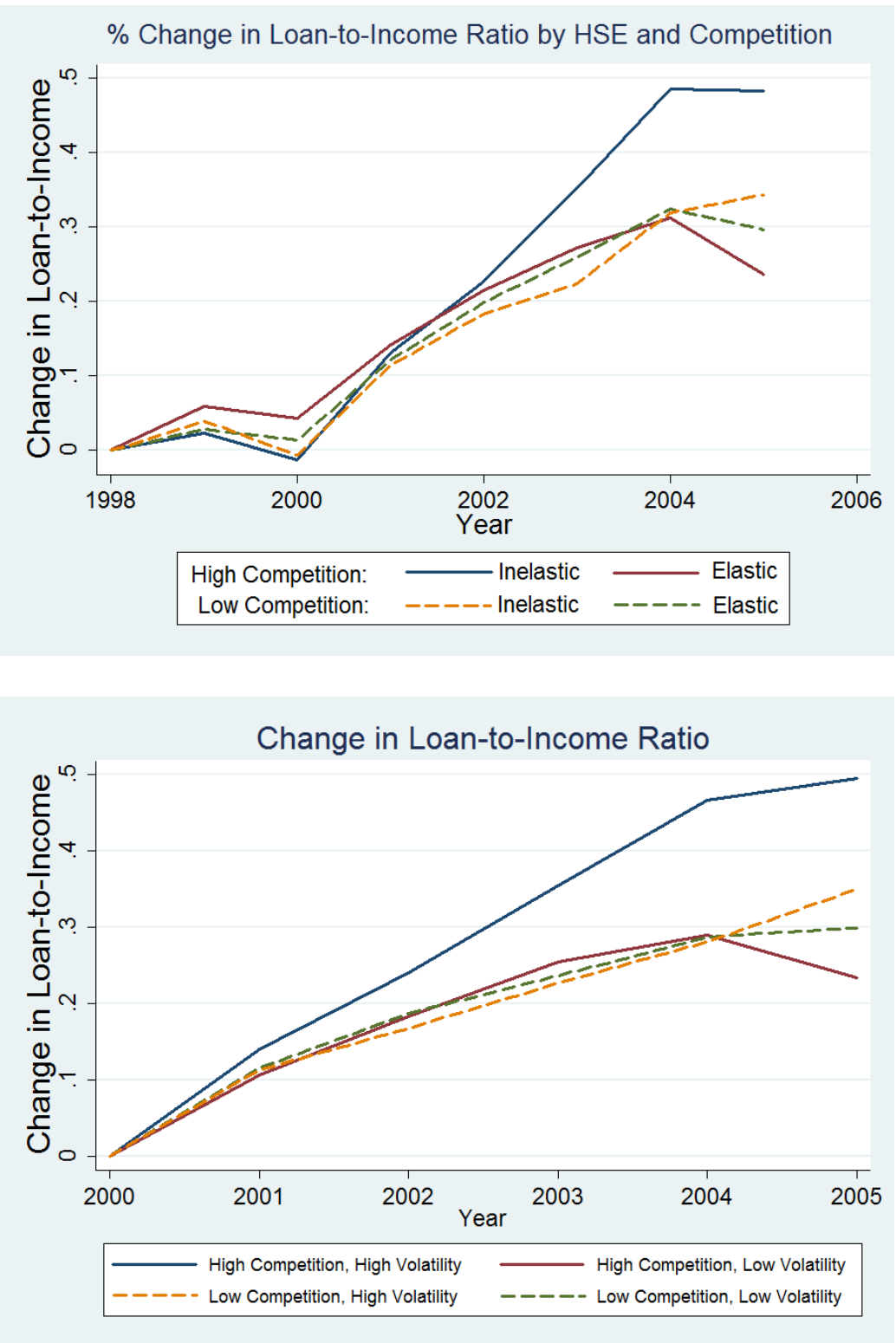


\section{Figure 5. Foreclosure and Bank Failure Rates During the Crisis}

The upper panel in this figure plots the foreclosure rate from 2007Q1 to 2008Q2 reported by the HUD against the Saiz housing supply elasticity. The left figure in the upper panel plots this relationship for U.S. counties with a competitive mortgage market and the right figure in the upper panel plots counties with a concentrated mortgage market. The lower panel in this figure plots the rate of bank failures from 2008Q1 to 2014Q2 reported by the FDIC against groups of the Saiz housing supply elasticity. The bank failure rate is computed as the number of bank failures in each group of supply elasticity divided by the total number of banks that had lending activities in the group as of 2005. The left figure in the lower panel plots the bank failure rate for areas with a competitive mortgage market and the right figure in the lower panel plots the bank failure rate for areas with a concentrated mortgage market.
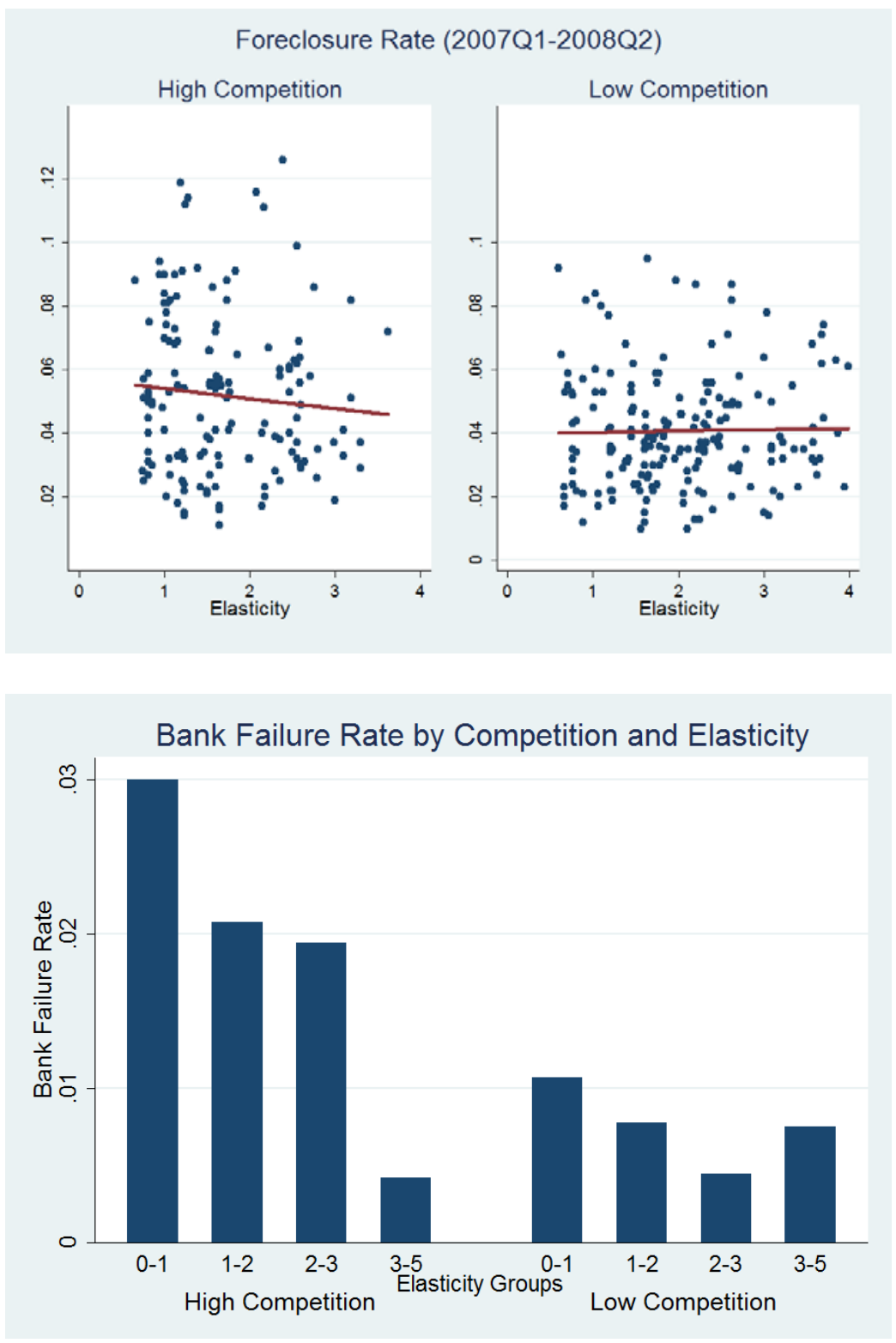


\section{Figure 6. Non-Financial Employment After the Crisis}

This figure plots the percentage change of employment in tradable non-financial sectors from 2007 to 2009 for establishments with size below 100 against housing supply elasticity at the U.S. county level. The left panel plots this relationship for counties with a competitive mortgage market and the right panel plots this relationship for counties with a concentrated mortgage market. Tradable sectors use the same definition as in Mian and Sufi (2014), which are sectors with high geographic concentration in production.

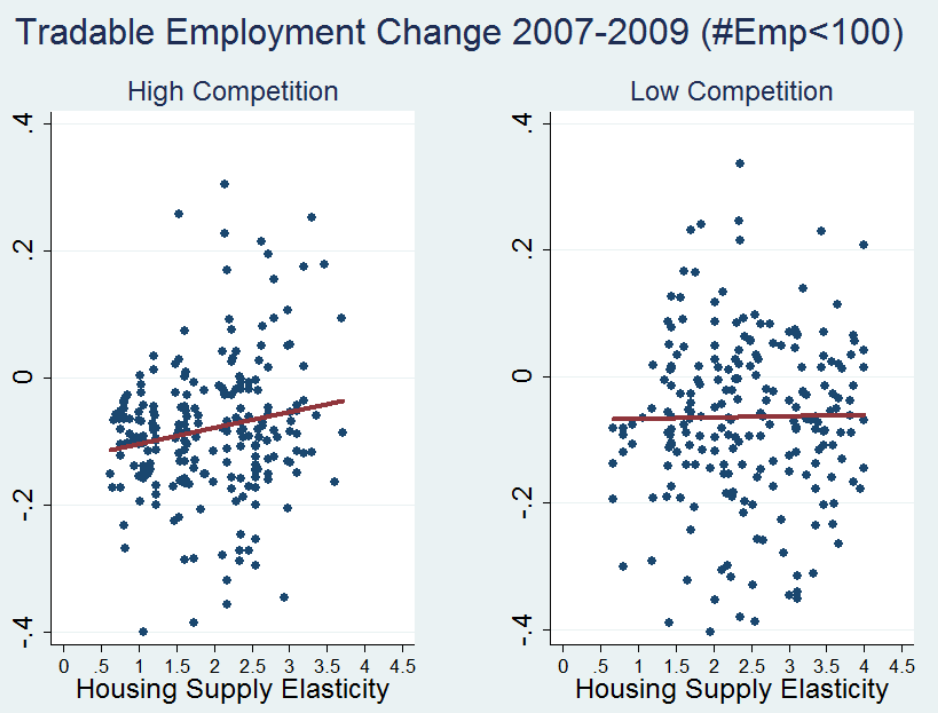




\section{Table 1. Summary Statistics}

This table presents summary statistics for the 789 U.S. counties covered in this sample where data is available. Total population in these counties account for 68 percent of total U.S. population as of 2000. The weighted mean and standard deviations use population in the county as of 2000 as weights.

\begin{tabular}{lccccccc}
\hline & $N$ & Mean & SD & $10^{\text {th }}$ & $90^{\text {th }}$ & $\begin{array}{c}\text { Weighted } \\
\text { Mean }\end{array}$ & $\begin{array}{c}\text { Weighted } \\
\text { SD }\end{array}$ \\
\hline CR (top-10), 2000 & 789 & 0.53 & 0.10 & 0.41 & 0.67 & 0.48 & 0.08 \\
CR (top-10), 1995 & 789 & 0.62 & 0.18 & 0.4 & 0.9 & 0.48 & 0.13 \\
Herfindahl Index, 2000 & 789 & 0.05 & 0.03 & 0.03 & 0.1 & 0.04 & 0.02 \\
House price volatility measure, 1982-1996 & 789 & 0.02 & 0.3 & -0.36 & 0.27 & 0.06 & 0.34 \\
House price volatility measure, 2001-2011 & 789 & 0.42 & 0.33 & 0.14 & 0.85 & 0.61 & 0.42 \\
Housing supply elasticity (Saiz) & 789 & 2.32 & 1.00 & 1.02 & 3.66 & 1.74 & 0.94 \\
Population, 2000 (thousands) & 789 & 243.3 & 522.08 & 20.72 & 569.95 & 1362.08 & 2160.09 \\
Percentage change in loan-to-income ratio, & 789 & 0.20 & 0.10 & 0.07 & 0.35 & 0.22 & 0.12 \\
2000-2005 & & & & & & \\
Change in acceptance rate, 2000-2005 & 789 & -0.06 & 0.05 & -0.12 & 0 & -0.07 & 0.04 \\
Change in loan-to-value ratio, 2001-2005 & 789 & -0.02 & 0.08 & -0.1 & 0.07 & -0.04 & 0.06 \\
Share of high-spread mortgage loans, & 789 & 0.26 & 0.08 & 0.17 & 0.36 & 0.27 & 0.08 \\
2005 & & & & & & & \\
Employment growth (tradable + & 789 & -0.03 & -0.08 & -0.11 & 0.05 & -0.03 & 0.05 \\
nontradable), 2007-2009 & & & & & & \\
Population growth, 2001-2005 & 789 & 0.05 & 0.07 & -0.01 & 0.17 & 0.04 & 0.07 \\
Employment growth, 2001-2005 & 789 & 0.05 & 0.12 & -0.07 & 0.18 & 0.02 & 0.09 \\
Finance/real estate employment growth, & 789 & 0.09 & 0.23 & -0.13 & 0.34 & 0.07 & 0.17 \\
2001-2005 & & & & & & \\
Weekly wage growth, 2001-2005 & 789 & 0.12 & 0.05 & 0.08 & 0.17 & 0.12 & 0.03 \\
Share of thrift institutions, 2005 & 789 & 0.13 & 0.05 & 0.07 & 0.2 & 0.16 & 0.05 \\
Share of securitized loans, 2005 & 789 & 0.54 & 0.09 & 0.4 & 0.65 & 0.59 & 0.07 \\
Share of investment homes, 2005 & 789 & 0.09 & 0.04 & 0.04 & 0.14 & 0.07 & 0.03 \\
Share of non-single-family homes, 2005 & 789 & 0.05 & 0.05 & 0.01 & 0.1 & 0.04 & 0.04 \\
\hline
\end{tabular}




\section{Table 2. First Stage Regression and Exclusion Restriction}

Column (1) of this table presents the first stage regression of historical house price volatility on housing supply inelasticity. Columns (2)-(3) show validity of using the long-run volatility predicting house price volatility during the 2000-2011 housing cycle. Column (4) shows the wage rate grov from 2000 to 2005 in relation to housing supply inelasticity, where weak correlation is found. House price volatility is defined as the house price growth in the boom period minus the change in house price during the bust. For the 1982-1996 housing cycle, house price volatility is defined as $\ln \left(\frac{H P_{1989}}{H P_{1982}}\right)-\ln \left(\frac{H P_{1996}}{H P_{1989}}\right)$; for the $2000-2011$ housing cycle, house price volatility is defined as $\ln \left(\frac{H P_{2006}}{H P_{2001}}\right)-\ln \left(\frac{H P_{2011}}{H P_{2006}}\right)$. Bank concentration is measured by the CR (top-10) as of 2000, i.e., the total market share of the top-10 lenders in the mortgage market. All variables are at the county level. All regressions are weighted by county population as of 2000 and standard errors are clustered at the CBSA level.

\begin{tabular}{|c|c|c|c|c|}
\hline & (1) & (2) & (3) & (4) \\
\hline \multirow[b]{2}{*}{ Housing Supply Inelasticity } & $\begin{array}{c}\text { HP Vol } \\
1982-1996\end{array}$ & \multicolumn{2}{|c|}{$\begin{array}{c}\text { HP Vol } \\
2000-2011\end{array}$} & $\begin{array}{c}\text { Wage Change, } \\
2000-2005\end{array}$ \\
\hline & $\begin{array}{c}0.56 * * * \\
(0.22)\end{array}$ & $\begin{array}{c}1.37 * * * \\
(0.15)\end{array}$ & $\begin{array}{c}1.34 * * * \\
(0.16)\end{array}$ & $\begin{array}{c}0.004 \\
(0.015)\end{array}$ \\
\hline CR (CR) & & & $\begin{array}{l}-0.18 \\
(0.32)\end{array}$ & \\
\hline Constant & $\begin{array}{c}-0.28 * * \\
(0.12)\end{array}$ & $\begin{array}{c}-0.28 * * * \\
(0.08)\end{array}$ & $\begin{array}{l}-0.20 \\
(0.20)\end{array}$ & $\begin{array}{c}0.15 * * * \\
(0.01)\end{array}$ \\
\hline$N$ & 789 & 789 & 789 & 789 \\
\hline$R^{2}$ & 0.10 & 0.37 & 0.37 & 0.00 \\
\hline
\end{tabular}




\section{Table 3. Loan-to-Income Ratio for National Banks versus Local Banks}

This table presents regressions of the change in loan-to-income ratio in a county on local house price volatility, instrumented by housing supply inelasticity (Saiz (2010)). The change in loan-to-income ratio is the percentage growth of the average loan-to-income ratio in a county from 2000 to 2005 . Bank concentration is measured by the CR (i.e., total market share of top-10 lenders) in that county as of 2000. National banks are defined as lending mortgages in at least ten states as of 2000; local banks are defined as lending mortgages in fewer than ten states as of 2000. All regressions are weighted by the number of households in a county as of 2000 . Standard errors are clustered at the CBSA level. $* * *, * * *$ denote statistical significance at the 1 percent, 5 percent, and 10 percent levels, respectively.

\begin{tabular}{|c|c|c|c|c|c|c|}
\hline & (1) & $(2)$ & (3) & $(4)$ & $(5)$ & $(6)$ \\
\hline & & ocal Banks & & National Banks & & \\
\hline HP Vol. & $\begin{array}{c}5.31 * * * \\
(0.96)\end{array}$ & $\begin{array}{c}4.66^{* * *} \\
(096)\end{array}$ & $\begin{array}{l}4.66^{* * * *} \\
(0.96)\end{array}$ & $\begin{array}{l}1.30 * * \\
(059)\end{array}$ & $\begin{array}{c}5.70^{* * *} \\
(0.95)\end{array}$ & $\begin{array}{c}3.87 * * * \\
(0.95)\end{array}$ \\
\hline \multirow[t]{2}{*}{ HP Vol. $\times$ CR } & $-7.51 * * *$ & $-7.63 * * *$ & $-7.63 * * *$ & -1.35 & $-8.36 * * *$ & $-6.32 * * *$ \\
\hline & $(1.66)$ & $(1.63)$ & $(1.63)$ & $(1.02)$ & $(1.66)$ & $(1.61)$ \\
\hline HP Vol. $\times$ CR $\times$ National Bank & & & & & $\begin{array}{r}4.48 * * \\
(2.00)\end{array}$ & $\begin{array}{l}4.48 * * \\
(2.01)\end{array}$ \\
\hline \multirow[t]{2}{*}{$\mathrm{CR}$} & $0.64 * * *$ & $0.59 * * *$ & $0.59 * * *$ & $0.17 * *$ & $0.79 * * *$ & $0.54 * * *$ \\
\hline & $(0.12)$ & $(0.12)$ & $(0.12)$ & $(0.07)$ & $(0.14)$ & $(0.10)$ \\
\hline \multirow[t]{2}{*}{ HP Vol. $\times$ National Bank } & & & & & $-2.17 *$ & $-2.17 *$ \\
\hline & & & & & $(1.15)$ & $(1.15)$ \\
\hline \multirow{2}{*}{$\mathrm{CR} \times$ National Bank } & & & & & $-0.42 * * *$ & $-0.42 * * *$ \\
\hline & & & & & $(1.11)$ & $(1.11)$ \\
\hline \multirow[t]{2}{*}{ National Bank } & & & & & $0.22 * * *$ & $0.22 * * *$ \\
\hline & & & & & $(0.06)$ & $(0.06)$ \\
\hline \multirow[t]{2}{*}{$\% \Delta$ Wage } & $0.47 * *$ & & $0.47 * *$ & $0.39^{* * *}$ & & $0.43 * * *$ \\
\hline & $(0.21)$ & & $(0.18)$ & $(0.10)$ & & $(0.12)$ \\
\hline \multirow[t]{2}{*}{$\log$ (Population) } & -0.01 & & -0.02 & $-0.012 * *$ & & $-0.015^{* *}$ \\
\hline & $(0.01)$ & & $(0.01)$ & $(0.006)$ & & $(0.007)$ \\
\hline \multirow[t]{2}{*}{$\% \Delta$ Population } & $-0.62 * * *$ & & $-0.44 * * *$ & $-0.20^{*}$ & & $-0.32 * *$ \\
\hline & $(0.23)$ & & $(0.22)$ & $(0.12)$ & & $(0.13)$ \\
\hline \multirow[t]{2}{*}{$\% \Delta$ Employment } & 0.18 & & 0.13 & $0.22^{* * *}$ & & $0.17 * *$ \\
\hline & $(0.14)$ & & $(0.12)$ & $(0.06)$ & & $(0.08)$ \\
\hline \multirow[t]{2}{*}{$\% \Delta$ Finance/RE Employment } & -0.02 & & -0.02 & -0.01 & & -0.01 \\
\hline & $(0.04)$ & & $(0.03)$ & $(0.02)$ & & $(0.02)$ \\
\hline \multirow[t]{2}{*}{ Share of Subprime, 2005} & & -0.07 & -0.04 & 0.02 & & -0.01 \\
\hline & & $(0.15)$ & $(0.14)$ & $(0.07)$ & & $(0.02)$ \\
\hline \multirow[t]{2}{*}{ Share of Thrift, 2005} & & $0.41^{*}$ & $0.49^{* *}$ & $0.85^{* * *}$ & & $0.67 * * *$ \\
\hline & & $(0.23)$ & $(0.24)$ & $(0.14)$ & & $(0.17)$ \\
\hline \multirow[t]{2}{*}{ Share of Refinancing, 2005} & & -0.28 & 0.22 & $2.48^{* * *}$ & & 1.35 \\
\hline & & $(1.35)$ & $(1.28)$ & $(0.83)$ & & $(0.85)$ \\
\hline \multirow[t]{2}{*}{ Share of Securitized, 2005} & & -0.15 & -0.00 & $0.51^{* * *}$ & & 0.25 \\
\hline & & $(0.17)$ & $(0.18)$ & $(0.13)$ & & $(0.12)$ \\
\hline \multirow[t]{2}{*}{ Share of Investment Homes } & & $0.64 *$ & 0.51 & $1.37^{* * *}$ & & $0.94 * * *$ \\
\hline & & $(0.36)$ & $(0.32)$ & $(0.24)$ & & $(0.20)$ \\
\hline \multirow[t]{2}{*}{ Share of Non-Single Family Homes } & & $-0.95 * * *$ & $-1.00 * * *$ & $-1.06^{* * *}$ & & $-1.03 * * *$ \\
\hline & & $(0.29)$ & $(0.28)$ & $(0.24)$ & & $(0.24)$ \\
\hline \multirow[t]{2}{*}{ Constant } & -0.08 & -0.10 & 0.03 & $-0.28 * *$ & $-0.26 * * *$ & $-0.23 * *$ \\
\hline & $(0.15)$ & $(0.15)$ & $(0.16)$ & $(0.13)$ & $(0.08)$ & $(0.10)$ \\
\hline$N$ & 789 & 789 & 789 & 789 & 1578 & 1578 \\
\hline$R^{2}$ & 0.36 & 0.42 & 0.45 & 0.67 & 0.35 & 0.52 \\
\hline
\end{tabular}


Table 4. Acceptance Rate for National Banks versus Local Banks

This table presents regressions of the change in acceptance rate (i.e., 1- denial rate) in the county on local house price volatility, instrumented by housing supply inelasticity (Saiz (2010)). The change in acceptance rate is the fraction of accepted loans in 2005 minus the fraction of accepted loans in 2000 . Bank concentration is measured by the CR (i.e., total market share of top-10 lenders) in that county as of 2000 . National banks are defined as lending mortgages in at least ten states as of 2000; local banks are defined as lending mortgages in fewer than ten states as of 2000 . All regressions are weighted by the number of households in a county as of 2000 . Standard errors are clustered at the CBSA level. ***,**,* denote statistical significance at the 1 percent, 5 percent and 10 percent levels, respectively.

\begin{tabular}{|c|c|c|c|c|c|c|}
\hline & (1) & (2) & (3) & (4) & (5) & (6) \\
\hline & & cal Banks & & National Banks & & \\
\hline \multirow[t]{2}{*}{ HP Vol. } & $2.09 * * *$ & $1.84 * * *$ & $1.40 * *$ & 0.51 & $2.09 * * *$ & $1.75 * * *$ \\
\hline & $(0.66)$ & $(0.69)$ & $(0.59)$ & $(0.35)$ & $(0.66)$ & $(0.66)$ \\
\hline \multirow[t]{2}{*}{ HP Vol. $\times$ CR } & $-2.79 * *$ & $-2.73 * *$ & $-1.77 *$ & -0.81 & $-2.79 * *$ & $-2.20 *$ \\
\hline & $(1.32)$ & $(1.36)$ & $(1.06)$ & $(0.63)$ & $(1.32)$ & $(1.15)$ \\
\hline \multirow[t]{2}{*}{ HP Vol. $\times$ CR $\times$ National Bank } & & & & & $1.81 *$ & $1.81 *$ \\
\hline & & & & & $(1.03)$ & $(1.03)$ \\
\hline \multirow[t]{2}{*}{$\mathrm{CR}$} & $0.16^{*}$ & $0.15^{*}$ & $0.18^{* *}$ & $-0.06^{*}$ & $0.16^{*}$ & $0.15^{*}$ \\
\hline & $(0.09)$ & $(0.09)$ & $(0.08)$ & $(0.03)$ & $(0.09)$ & $(0.08)$ \\
\hline \multirow[t]{2}{*}{ HP Vol. $\times$ National Bank } & & & & & $-1.59 * * * *$ & $-1.59 * * * *$ \\
\hline & & & & & $(0.54)$ & $(0.54)$ \\
\hline \multirow[t]{2}{*}{$\mathrm{CR} \times$ National Bank } & & & & & $-0.17 * *$ & $-0.17 * *$ \\
\hline & & & & & $(0.08)$ & $(0.08)$ \\
\hline \multirow[t]{2}{*}{ National Bank } & & & & & 0.04 & 0.04 \\
\hline & & & & & $(0.04)$ & $(0.04)$ \\
\hline \multirow[t]{2}{*}{$\% \Delta$ Wage } & & $0.46 * * *$ & $0.44 * *$ & 0.07 & & $0.25^{* * *}$ \\
\hline & & $(0.21)$ & $(0.14)$ & $(0.06)$ & & $(0.08)$ \\
\hline \multirow[t]{2}{*}{$\log$ (Population) } & & 0.00 & 0.00 & $-0.01 *$ & & -0.00 \\
\hline & & $(0.01)$ & $(0.01)$ & $(0.00)$ & & $(0.01)$ \\
\hline \multirow[t]{2}{*}{$\% \Delta$ Population } & & -0.07 & -0.23 & -0.08 & & -0.15 \\
\hline & & $(0.13)$ & $(0.14)$ & $(0.08)$ & & $(0.10)$ \\
\hline \multirow[t]{2}{*}{$\% \Delta$ Employment } & & -0.05 & -0.04 & $0.07 * *$ & & 0.02 \\
\hline & & $(0.09)$ & $(0.08)$ & $(0.04)$ & & $(0.05)$ \\
\hline \multirow[t]{2}{*}{$\% \Delta$ Finance/RE Employment } & & -0.00 & -0.01 & -0.00 & & -0.00 \\
\hline & & $(0.03)$ & $(0.02)$ & $(0.02)$ & & $(0.02)$ \\
\hline \multirow[t]{2}{*}{ Share of Thrift, 2005} & & & 0.02 & $-0.13 *$ & & -0.06 \\
\hline & & & $(0.13)$ & $(0.07)$ & & $(0.08)$ \\
\hline \multirow[t]{2}{*}{ Share of Refinancing, 2005} & & & $-3.17 * *$ & $1.00^{* * *}$ & & $-1.09 * *$ \\
\hline & & & $(0.70)$ & $(0.36)$ & & $(0.45)$ \\
\hline \multirow[t]{2}{*}{ Share of Securitized, 2005} & & & 0.16 & $0.51 * * *$ & & 0.08 \\
\hline & & & $(0.16)$ & $(0.13)$ & & $(0.11)$ \\
\hline \multirow[t]{2}{*}{ Share of Investment Homes } & & & 0.09 & -0.00 & & 0.01 \\
\hline & & & $(0.23)$ & $(0.07)$ & & $(0.14)$ \\
\hline \multirow[t]{2}{*}{ Share of Non-Single Family Homes } & & & $-0.41 * * *$ & -0.08 & & $-0.19 *$ \\
\hline & & & $(0.15)$ & $(0.10)$ & & $(0.10)$ \\
\hline \multirow[t]{2}{*}{ Constant } & -0.08 & -0.12 & $-0.21 *$ & $-0.12 * *$ & -0.04 & -0.06 \\
\hline & $(0.15)$ & $(0.11)$ & $(0.13)$ & $(0.04)$ & $(0.05)$ & $(0.08)$ \\
\hline$N$ & 789 & 789 & 789 & 789 & 1578 & 1578 \\
\hline$R^{2}$ & 0.17 & 0.20 & 0.27 & 0.11 & 0.35 & 0.38 \\
\hline
\end{tabular}


Table 5. Combining National and Local Banks

This table presents regressions of the change in loan-to-income ratio (both in percentage and in absolute value) and the change in acceptance rate for all banks in the county on local house price volatility, instrumented by housing supply inelasticity (Saiz (2010)). Bank concentration is measured by the CR (i.e., total market share of top-10 lenders) in that county as of 2000 . All variables are at the county level. All regressions are weighted by the number of households in a county as of 2000. Standard errors are clustered at the CBSA level.

\begin{tabular}{|c|c|c|c|c|c|c|c|c|}
\hline & (1) & (2) & (3) & (4) & (5) & (6) & $(7)$ & $(8)$ \\
\hline \multirow{3}{*}{ HP Vol. } & \multicolumn{3}{|c|}{$\Delta \ln$ (Loan-to-Income), 2000-2005 } & \multicolumn{3}{|c|}{$\Delta$ Loan-to-Income, $2000-2005$} & \multicolumn{2}{|c|}{$\Delta$ Acceptance Rate, $2000-2005$} \\
\hline & $3.86^{* * *}$ & $3.19 * * *$ & $2.00 * * *$ & $8.44 * * *$ & $6.72 * * *$ & $4.14 * * *$ & $0.66^{* *}$ & $0.54 *$ \\
\hline & $(0.66)$ & $(0.64)$ & $(0.51)$ & $(1.87)$ & $(1.68)$ & $(1.23)$ & $(0.66)$ & $(0.30)$ \\
\hline \multirow[t]{2}{*}{ HP Vol. $\times$ CR } & $-4.92 * * *$ & $-3.78 * * *$ & $-3.08 * * *$ & $-9.26 * * *$ & $-6.77 * *$ & $-6.05 * * *$ & $-0.96 *$ & $-0.81^{+}$ \\
\hline & $(1.32)$ & $(1.14)$ & $(0.88)$ & $(3.28)$ & $(3.13)$ & $(2.11)$ & $(0.54)$ & $(0.53)$ \\
\hline \multirow[t]{2}{*}{$\mathrm{CR}$} & $0.43^{* * *}$ & $0.39 * * *$ & $0.25 * *$ & $0.82 * * *$ & $0.85^{* * *}$ & $0.57 * *$ & 0.04 & 0.01 \\
\hline & $(0.09)$ & $(0.09)$ & $(0.06)$ & $(0.19)$ & $(0.21)$ & $(0.16)$ & $(0.03)$ & $(0.03)$ \\
\hline \multirow[t]{2}{*}{$\% \Delta$ Wage } & & $0.47 * * *$ & $0.48 * * *$ & & $0.76^{* * *}$ & $0.82 * * *$ & & $0.15^{* *}$ \\
\hline & & $(0.14)$ & $(0.10)$ & & $(0.35)$ & $(0.26)$ & & $(0.06)$ \\
\hline \multirow[t]{2}{*}{$\log ($ Population $)$} & & 0.00 & $-0.02 * * *$ & & 0.03 & $-0.04 * * *$ & & $-0.004 *$ \\
\hline & & $(0.01)$ & $(0.01)$ & & $(0.02)$ & $(0.01)$ & & $(0.002)$ \\
\hline \multirow[t]{2}{*}{$\% \Delta$ Population } & & $-0.41 * * *$ & $-0.22 * *$ & & $-0.72 * *$ & $-0.56^{* *}$ & & -0.05 \\
\hline & & $(0.14)$ & $(0.10)$ & & $(0.36)$ & $(0.26)$ & & $(0.05)$ \\
\hline \multirow[t]{2}{*}{$\% \Delta$ Employment } & & $0.33^{* * *}$ & $0.23 * * *$ & & $0.63 * *$ & $0.46^{* * *}$ & & $0.05 * *$ \\
\hline & & $(0.09)$ & $(0.06)$ & & $(0.25)$ & $(0.14)$ & & $(0.02)$ \\
\hline \multirow[t]{2}{*}{$\% \Delta$ Finance/RE Employment } & & -0.00 & -0.02 & & 0.08 & 0.02 & & 0.00 \\
\hline & & $(0.03)$ & $(0.02)$ & & $(0.07)$ & $(0.05)$ & & $(0.01)$ \\
\hline \multirow[t]{2}{*}{ Share of Subprime, 2005} & & & -0.02 & & & -0.18 & & $0.09 * * *$ \\
\hline & & & $(0.09)$ & & & $(0.17)$ & & $(0.03)$ \\
\hline \multirow[t]{2}{*}{ Share of Thrift, 2005} & & & $0.62 * * *$ & & & $1.52 * * *$ & & -0.05 \\
\hline & & & $(0.13)$ & & & $(0.31)$ & & $(0.04)$ \\
\hline \multirow[t]{2}{*}{ Share of Refinancing, 2005} & & & $3.31 * * *$ & & & $11.74 * * *$ & & $2.28 * * *$ \\
\hline & & & $(0.98)$ & & & $(2.36)$ & & $(0.26)$ \\
\hline \multirow[t]{2}{*}{ Share of Securitized, 2005} & & & $0.35^{* * *}$ & & & $1.14^{* * *}$ & & -0.05 \\
\hline & & & $(0.11)$ & & & $(0.26)$ & & $(0.06)$ \\
\hline \multirow[t]{2}{*}{ Share of Investment Homes } & & & $1.18^{* * *}$ & & & $2.42^{* * *}$ & & $0.30 * * *$ \\
\hline & & & $(0.20)$ & & & $(0.50)$ & & $(0.09)$ \\
\hline \multirow[t]{2}{*}{ Share of Non-Single Family Homes } & & & $-1.01 * * *$ & & & $-2.31 * * *$ & & 0.08 \\
\hline & & & $(0.22)$ & & & $(0.52)$ & & $(0.06)$ \\
\hline \multirow{2}{*}{ Share of National Banks, 2000} & & & $0.16^{* * *}$ & & & $0.67 * * *$ & & $0.09 * * *$ \\
\hline & & & $(0.05)$ & & & $(0.14)$ & & $(0.03)$ \\
\hline \multirow[t]{2}{*}{ Constant } & -0.06 & -0.13 & -0.04 & -0.14 & $-0.63 *$ & $-0.92 * * *$ & $-0.10 * * *$ & $-0.14 * * *$ \\
\hline & $(0.05)$ & $(0.11)$ & $(0.17)$ & $(0.11)$ & $(0.36)$ & $(0.26)$ & $(0.01)$ & $(0.04)$ \\
\hline$N$ & 789 & 789 & 789 & 789 & 789 & 789 & 789 & 789 \\
\hline$R^{2}$ & 0.39 & 0.44 & 0.67 & 0.44 & 0.48 & 0.72 & 0.35 & 0.33 \\
\hline
\end{tabular}




\section{Table 6. Robustness Using the Herfindahl Index}

This table presents regressions of the change in loan-to-income ratio and acceptance rate in the county on local house price volatility, instrumented by housing supply inelasticity (Saiz (2010)). The change in loan-to-income ratio is the percentage growth of the average loan-to-income ratio in a county from 2000 to 2005. Bank concentration is measured by the Herfindahl index in that county as of 2000. National banks are defined as lending mortgages in at least ten states as of 2000; local banks are defined as lending mortgages in less than ten states as of 2000 . All regressions are weighted by the number of population in the county as of 2000. Standard errors are clustered at the CBSA level.

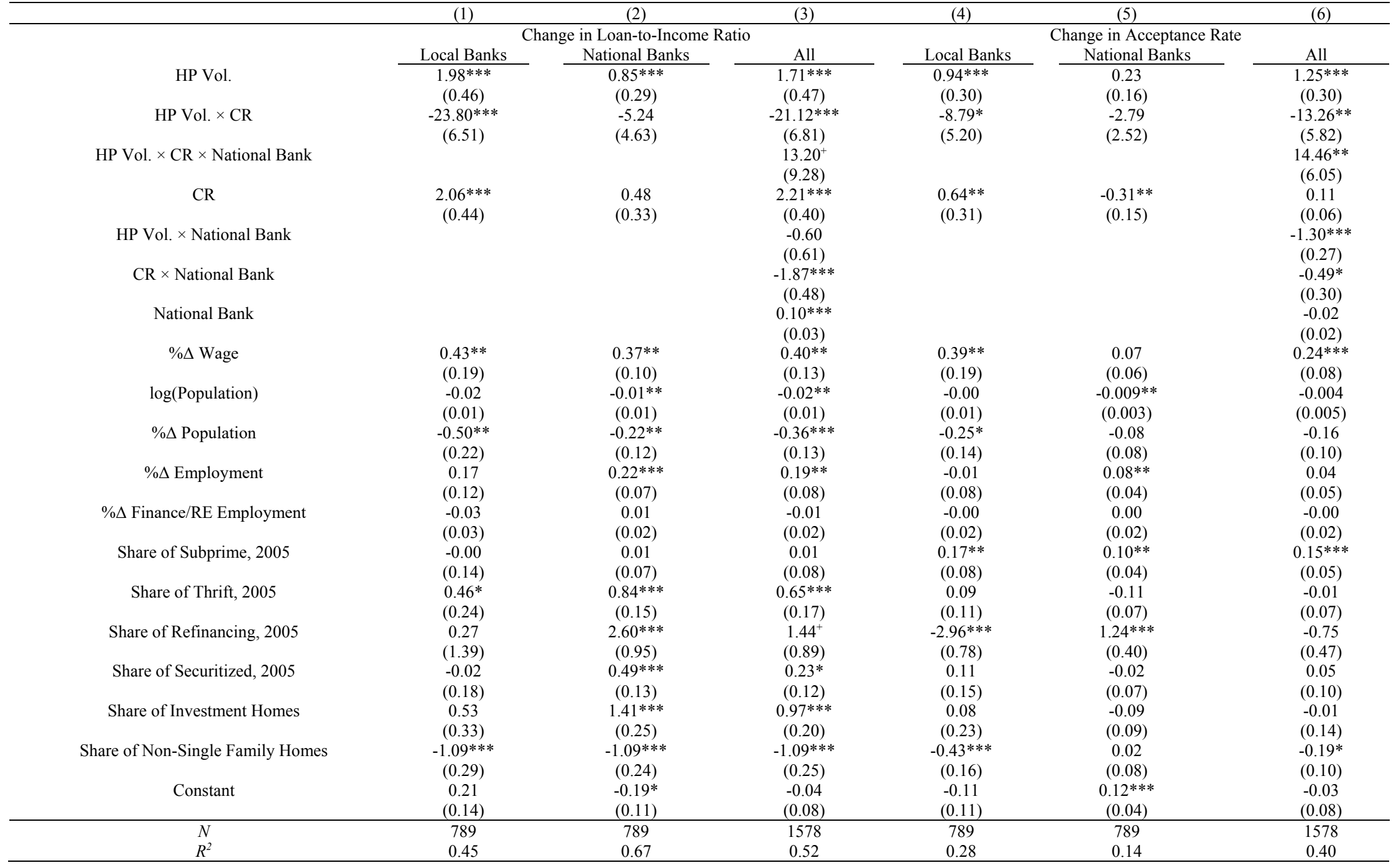


Table 7. Robustness Using Alternative Measures for Loan Risk and House Price Volatility

Columns (1)-(2) of this table present regressions of the share of high-rate-spread mortgage loans in the county as of 2005 on local house price volatility, instrumented by housing supply inelasticity (Saiz (2010)). Columns (3)-(4) report the regression of the percentage change in the LTV ratio from 2001 to 2005 in the county on the instrumented local house price volatility. Columns (5)-(6) report the regression of the percentage change in the loan-to-income ratio from 2000 to 2005 on realized house price volatility between 2000 and 2011. The share of high-rate-spread loans is the fraction of loans that have a rate spread higher than the threshold that the HMDA requires to report after 2004. The loan-to-value ratio is computed using survey data from MIRS at the zip-code level and weighting zipcode level data appropriately by population to construct the county level data. Bank concentration is measured by the CR (i.e., total market share of top-10 lenders) in that county as of 2000. All regressions are weighted by the number of population in the county as of 2000. Standard errors are clustered at the CBSA level.

\begin{tabular}{|c|c|c|c|c|c|c|}
\hline \multirow[b]{3}{*}{ HP Vol. } & (1) & (2) & (3) & (4) & (5) & (6) \\
\hline & \multicolumn{2}{|c|}{ Share of high-spread loans } & \multicolumn{2}{|c|}{ Percentage change in LTV } & \multicolumn{2}{|c|}{$\% \Delta$ LTI, Realized HP Volatility } \\
\hline & $1.03 * * *$ & $0.84 *$ & 0.37 & 0.36 & $0.49 * *$ & $0.59 * * *$ \\
\hline \multirow{3}{*}{ HP Vol. $\times$ CR } & $(0.51)$ & $(0.44)$ & $(0.35)$ & $(0.32)$ & $(0.21)$ & $(0.17)$ \\
\hline & $-2.57 * * *$ & $-2.00 * *$ & $-0.88^{+}$ & $-0.84^{+}$ & $-0.62^{+}$ & $-0.86 * * *$ \\
\hline & $(1.00)$ & $(0.80)$ & $(0.61)$ & $(0.58)$ & $(0.40)$ & $(0.33)$ \\
\hline \multirow{2}{*}{ HP Vol. $\times \mathrm{CR} \times$ National Bank } & & & & & $0.82 *$ & $0.82 *$ \\
\hline & & & & & $(0.43)$ & $(0.44)$ \\
\hline \multirow[t]{2}{*}{$\mathrm{CR}$} & $-0.27 * * *$ & $-0.18 * * *$ & $0.08 * *$ & 0.07 & 0.77 & $0.59 * * *$ \\
\hline & $(0.03)$ & $(0.06)$ & $(0.04)$ & $(0.04)$ & $(0.21)$ & $(0.16)$ \\
\hline \multirow[t]{2}{*}{ HP Vol. $\times$ National Bank } & & & & & $-0.33^{+}$ & $-0.33^{+}$ \\
\hline & & & & & $(0.22)$ & $(0.22)$ \\
\hline \multirow[t]{2}{*}{$\mathrm{CR} \times$ National Bank } & & & & & $-0.61 * * *$ & $-0.61 * * *$ \\
\hline & & & & & $(0.19)$ & $(0.19)$ \\
\hline \multirow[t]{2}{*}{ National Bank } & & & & & $0.28 * * *$ & $0.28 * * *$ \\
\hline & & & & & $(0.10)$ & $(0.10)$ \\
\hline \multirow[t]{2}{*}{$\% \Delta$ Wage } & & 0.06 & & -0.09 & & -0.03 \\
\hline & & $(0.10)$ & & $(0.06)$ & & $(0.12)$ \\
\hline \multirow[t]{2}{*}{$\log ($ Population $)$} & & $-0.01 * *$ & & -0.005 & & $-0.02 * * *$ \\
\hline & & $(0.01)$ & & $(0.004)$ & & $(0.00)$ \\
\hline \multirow[t]{2}{*}{$\% \Delta$ Population } & & -0.06 & & $-0.10^{+}$ & & $-0.74^{* *+}$ \\
\hline & & $(0.11)$ & & $(0.07)$ & & $(0.11)$ \\
\hline \multirow[t]{2}{*}{$\% \Delta$ Employment } & & -0.07 & & -0.04 & & $0.09^{+}$ \\
\hline & & $(0.05)$ & & $(0.04)$ & & $(0.06)$ \\
\hline \multirow{2}{*}{$\% \Delta$ Finance/RE Employment } & & -0.02 & & $-0.02 *$ & & $0.04 *$ \\
\hline & & $(0.02)$ & & $(0.01)$ & & $(0.02)$ \\
\hline \multirow[t]{2}{*}{ Share of Thrift, 2005} & & $-0.47 * * *$ & & -0.07 & & $0.36^{* * *}$ \\
\hline & & $(0.10)$ & & $(0.08)$ & & $(0.13)$ \\
\hline \multirow[t]{2}{*}{ Share of Refinancing, 2005} & & 0.19 & & -0.23 & & $1.90^{* * *}$ \\
\hline & & $(0.69)$ & & $(0.67)$ & & $(0.55)$ \\
\hline \multirow[t]{2}{*}{ Share of Securitized, 2005} & & $0.23 * *$ & & -0.07 & & -0.08 \\
\hline & & $(0.11)$ & & $(0.08)$ & & $(0.12)$ \\
\hline \multirow[t]{2}{*}{ Share of Investment Homes } & & 0.10 & & -0.17 & & $0.56^{* * *}$ \\
\hline & & $(0.22)$ & & $(0.17)$ & & $(0.20)$ \\
\hline \multirow[t]{2}{*}{ Share of Non-Single Family Homes } & & 0.05 & & $0.50 * * *$ & & $-0.43 * * *$ \\
\hline & & $(0.11)$ & & $(0.10)$ & & $(0.16)$ \\
\hline \multirow{2}{*}{ Constant } & $0.40 * * *$ & $0.12 *$ & $-0.016 * * *$ & 0.06 & $-0.28 * *$ & 0.11 \\
\hline & $(0.03)$ & $(0.07)$ & $(0.004)$ & $(0.10)$ & $(0.12)$ & $(0.13)$ \\
\hline$N$ & 789 & 789 & 789 & 789 & 1578 & 1578 \\
\hline$R^{2}$ & 0.17 & 0.32 & 0.14 & 0.29 & 0.43 & 0.61 \\
\hline
\end{tabular}




\section{Table 8. Banks in the Same County}

This table presents regressions of bank-level average loan-to-income change from 2000 to 2005 in a given county on the average Herfindahl index for the bank. Bank-level Herfindahl index (wHHI), representing bank concentration, is the weighted average HHI of counties in which the bank had mortgage lending activities in 2001. To ensure that banks in each county are comparable, we require that each bank must have at least 1 percent and at most 50 percent of its total mortgage loans in the county and that each county must have at least 15 banks for the inclusion of county fixed effects. Standard errors are clustered at the county level.

\begin{tabular}{|c|c|c|c|c|c|c|}
\hline & (1) & (2) & (3) & (4) & (5) & (6) \\
\hline & \multicolumn{6}{|c|}{ Percentage change in loan-to-income ratio, 2000-2005 } \\
\hline Bank Average Local Concentration & -0.31 & $\begin{array}{c}-3.19 * * \\
(1.30)\end{array}$ & $\begin{array}{c}-3.44^{*} \\
(2.36)\end{array}$ & -0.17 & $-0.75^{* *}$ & $-1.07^{* * *}$ \\
\hline Bank Average Local Concentration $\times$ Elasticity & & $\begin{array}{c}(1.30) \\
1.50 * * *\end{array}$ & $\begin{array}{c}(2.36) \\
1.68 * * *\end{array}$ & $(0.21)$ & $\begin{array}{l}(1.30) \\
0.35 * * *\end{array}$ & $\begin{array}{c}(0.33) \\
0.42 * * *\end{array}$ \\
\hline Bank Average Local Concentration $\times$ Elasticity & & $(0.56)$ & $(0.57)$ & & $(0.13)$ & $(0.13)$ \\
\hline Share of Loans Securitized & & & $\begin{array}{c}-0.03 \\
(0.02)\end{array}$ & & & $\begin{array}{c}0.05^{*} \\
(0.03)\end{array}$ \\
\hline Concentration Measure & HHI & HHI & HHI & C.R. & C.R. & C.R. \\
\hline County Fixed Effects & $\mathrm{Y}$ & $\mathrm{Y}$ & $\mathrm{Y}$ & $\mathrm{Y}$ & $\mathrm{Y}$ & $\mathrm{Y}$ \\
\hline Bank Size and Type Controls & $\mathrm{N}$ & $\mathrm{N}$ & Y & $\mathrm{N}$ & $\mathrm{N}$ & Y \\
\hline Bank Headquarter State FEs & $\mathrm{N}$ & $\mathrm{N}$ & $\mathrm{Y}$ & $\mathrm{N}$ & $\mathrm{N}$ & $\mathrm{Y}$ \\
\hline$N$ & 2,159 & 2,159 & 2,159 & 2,159 & 2,159 & 2,159 \\
\hline$R^{2}$ & 0.06 & 0.07 & 0.08 & 0.06 & 0.07 & 0.10 \\
\hline
\end{tabular}


Table 9. Bank Loan Portfolio Shift and Local Competition

This table reports regressions of the 2001-2005 change in the intentional changes in weighted average elasticity of counties in which the bank had mortgage lending activities. This intentional change is measured by the actual change in weighted average elasticity for the bank minus what the average elasticity would have been if the bank maintained constant market shares in each county from 2001 to 2005. Bank-level Herfindahl index (wHHI), representing bank concentration, is the weighted average HHI of counties in which the bank had mortgage lending activities in 2001. Since the elasticity measure of some counties is missing, we require that at least the elasticity measure should cover at least 70 percent of the mortgage portfolio of the bank. To ensure that my results are not driven by extreme cases, we require that each bank issued at least 100 mortgage loans as of 2001 and winsorize the change in average elasticity at 2.5 percent at each tail of its distribution. Standard errors are robust. $*^{* *}, *^{*}, *$ denote statistical significance at the 1percent, 5 percent and 10 percent levels.

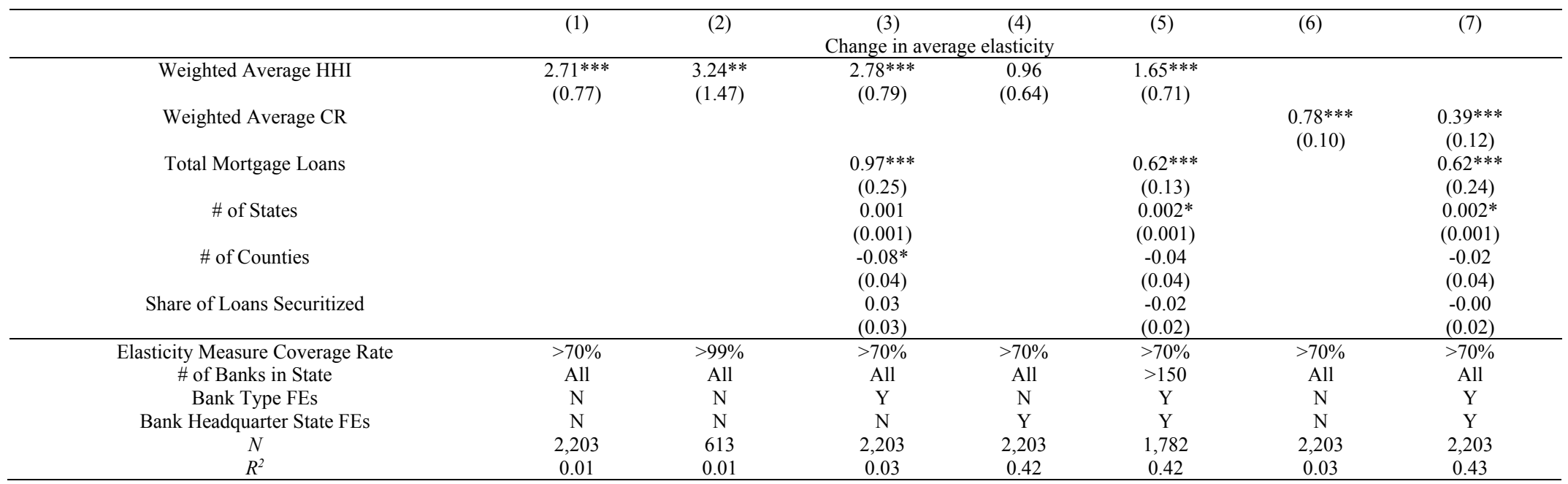




\section{Table 10. Change in Employment in the Real Sectors}

This table presents regression results of the change in non-financial sector employment from 2007 to 2009 in the county on local house price volatility, instrumented by housing supply inelasticity (Saiz (2010)). We particularly exclude finance/insurance, real estate and construction industries. Bank concentration measured by the CR (i.e., total market share of top-10 lenders) in that county as of 2000 . All regressions are weighted by the number of population in the county of 2000. Standard errors are clustered at the CBSA level.

\begin{tabular}{|c|c|c|c|c|c|c|c|c|c|}
\hline & $(1)$ & $(2)$ & (3) & $(4)$ & $(5)$ & $(6)$ & (7) & $(8)$ & (9) \\
\hline & \multicolumn{9}{|c|}{ Percentage Change in Employment, 2007-2009 } \\
\hline HP Vol. & $\begin{array}{l}-0.08^{*} \\
(0.04)\end{array}$ & $\begin{array}{l}-0.14 \\
(0.10)\end{array}$ & $\begin{array}{c}-0.30 * * \\
(0.13)\end{array}$ & $\begin{array}{l}-0.20^{+} \\
(0.13)\end{array}$ & $\begin{array}{l}-0.16 \\
(0.12)\end{array}$ & $\begin{array}{c}-0.18^{* *} \\
(0.08)\end{array}$ & $-0.35 * * *$ & $\begin{array}{l}-0.34 * \\
(0.19)\end{array}$ & $\begin{array}{l}-0.04 \\
(0.24)\end{array}$ \\
\hline HP Vol. $\times$ CR & & $\begin{array}{c}2.01 \\
(1.56)\end{array}$ & $\begin{array}{l}6.01^{* *} \\
(2.43)\end{array}$ & $\begin{array}{l}4.82 * * \\
(2.40)\end{array}$ & $\begin{array}{l}4.24^{*} \\
(2.33)\end{array}$ & $\begin{array}{l}3.08 * * \\
(1.35)\end{array}$ & $\begin{array}{l}4.87^{*} \\
(2.64)\end{array}$ & $\begin{array}{c}3.67 \\
(4.06)\end{array}$ & $\begin{array}{c}1.30 \\
(4.71)\end{array}$ \\
\hline $\mathrm{CR}$ & & $\begin{array}{c}(1.00) \\
0.18 \\
(0.12)\end{array}$ & $\begin{array}{l}(2.45) \\
-0.04 \\
(0.17)\end{array}$ & $\begin{array}{l}(2.40) \\
-0.06 \\
(0.16)\end{array}$ & $\begin{array}{c}(2.55) \\
0.16 \\
(0.16)\end{array}$ & $\begin{array}{l}-0.01 \\
(0.10)\end{array}$ & $\begin{array}{c}-0.01 \\
(0.10)\end{array}$ & $\begin{array}{c}0.39 \\
(0.29)\end{array}$ & $\begin{array}{c}0.28 \\
(0.33)\end{array}$ \\
\hline Debt-to-Income, 2006 & & & & $\begin{array}{c}-0.010^{* * *} \\
(0.16)\end{array}$ & & & & & \\
\hline $\log$ (Population) & & & & & $\begin{array}{c}0.002 \\
(0.003)\end{array}$ & & & & \\
\hline$\% \Delta$ Population & & & & & $\begin{array}{c}0.86^{* * *} \\
(0.36)\end{array}$ & & & & \\
\hline Finance/Real Estate Employment Share, 2005 & & & & & $\begin{array}{l}0.28^{* *} \\
(0.09)\end{array}$ & & & & \\
\hline Non-Tradable Employment Share, 2005 & & & & & $\begin{array}{c}0.10 \\
(0.06)\end{array}$ & & & & \\
\hline Share of Subprime, 2005 & & & & & $\begin{array}{c}0.03 \\
(0.04)\end{array}$ & & & & \\
\hline Share of Thrift, 2005 & & & & & $\begin{array}{c}0.03 \\
(0.05)\end{array}$ & & & & \\
\hline Share of Securitized, 2005 & & & & & $\begin{array}{c}0.00 \\
(0.05)\end{array}$ & & & & \\
\hline Share of Investment Homes & & & & & $\begin{array}{c}0.34 * * * \\
(0.09)\end{array}$ & & & & \\
\hline Constant & $\begin{array}{c}-0.03 * * * \\
(0.00) \\
\end{array}$ & $\begin{array}{l}-0.13 \\
(0.01)\end{array}$ & $\begin{array}{c}-0.03 * * * \\
(0.01) \\
\end{array}$ & $\begin{array}{l}-0.01 \\
(0.01) \\
\end{array}$ & $\begin{array}{c}-0.16^{* * *} \\
(0.05) \\
\end{array}$ & $\begin{array}{c}-0.02 * * \\
(0.01)\end{array}$ & $\begin{array}{l}-0.01 \\
(0.01)\end{array}$ & $\begin{array}{c}-0.03 * \\
(0.02) \\
\end{array}$ & $\begin{array}{c}-0.07 * * * \\
(0.02) \\
\end{array}$ \\
\hline Firm Size & All & All & All & All & All & $(0,20]$ & $(20,50]$ & $(50,100]$ & $(100,500]$ \\
\hline$N$ & 789 & 789 & 751 & 751 & 751 & 751 & 751 & 725 & 725 \\
\hline$R^{2}$ & 0.01 & 0.02 & 0.02 & 0.03 & 0.17 & 0.03 & 0.02 & 0.02 & 0.01 \\
\hline
\end{tabular}




\section{Table 11. Change in Tradable-Sector Employment in the Real Sectors}

This table presents regressions of the percentage change in employment of tradable sectors in the county on local house price volatility, instrumented by housing supply inelasticity (Saiz (2010)). The change in tradable employment is the percentage change of total employment in the county from 2007 to 2009 , where tradable industries are defined similarly as in Mian and Sufi (2014). Bank concentration is measured by the CR (i.e., total market share of top-10 lenders) in that county as of 2000. Columns (5)-(6) also report regression results using the 2003-2007 change as placebo tests. All regressions are weighted by the number of population in the county as of 2000. Standard errors are clustered at the CBSA level.

\begin{tabular}{|c|c|c|c|c|c|c|}
\hline & $(1)$ & $(2)$ & $(3)$ & $(4)$ & $(5)$ & $(6)$ \\
\hline \multirow[b]{2}{*}{ HP Vol. } & \multicolumn{4}{|c|}{ Percentage Change in Employment, 2007-2009 } & \multicolumn{2}{|c|}{$\begin{array}{l}\text { Percentage Change in } \\
\text { Employment, 2003-2007 }\end{array}$} \\
\hline & $\begin{array}{l}-0.20^{*} \\
(0.12)\end{array}$ & $\begin{array}{c}-1.32 * * \\
(0.56)\end{array}$ & $\begin{array}{c}-1.38^{* * *} \\
(0.54)\end{array}$ & $\begin{array}{l}-1.45^{*} \\
(0.79)\end{array}$ & $\begin{array}{l}-0.69 \\
(1.10)\end{array}$ & $\begin{array}{c}0.35 \\
(0.95)\end{array}$ \\
\hline HP Vol. $\times$ CR & & $2.25 * *$ & $2.23 * *$ & $2.41 *$ & 0.80 & $4.87 *$ \\
\hline & & $(1.02)$ & $(1.02)$ & $(1.42)$ & $(1.86)$ & $(2.64)$ \\
\hline CR & & -0.04 & -0.05 & -0.06 & -0.03 & -0.01 \\
\hline & & $(0.08)$ & $(0.17)$ & $(0.10)$ & $(0.11)$ & $(0.10)$ \\
\hline$\% \Delta$ Population, 2007-2009 & & & & $\begin{array}{c}0.03 \\
(0.39)\end{array}$ & & \\
\hline$\% \Delta$ Population, 2003-2007 & & & & & & $\begin{array}{c}0.89 * * * \\
(0.19)\end{array}$ \\
\hline Debt-to-Income, 2006 & & & $\begin{array}{c}0.01 \\
(0.02)\end{array}$ & $\begin{array}{c}0.01 \\
(0.03)\end{array}$ & & \\
\hline $\log ($ Population $)$ & & & & $\begin{array}{c}0.01 \\
(0.01)\end{array}$ & & \\
\hline Finance/Real Estate Employment Share, 2005 & & & & $\begin{array}{l}-0.00 \\
(0.01)\end{array}$ & & \\
\hline Non-Tradable Employment Share, 2005 & & & & $\begin{array}{c}0.11 \\
(0.18)\end{array}$ & & \\
\hline Share of Subprime, 2005 & & & & $\begin{array}{l}-0.07 \\
(0.11)\end{array}$ & & \\
\hline Share of Thrift, 2005 & & & & $\begin{array}{l}-0.14 \\
(0.21)\end{array}$ & & \\
\hline Share of Securitized, 2005 & & & & $\begin{array}{c}0.13 \\
(0.16)\end{array}$ & & \\
\hline Share of Investment Homes & & & & $\begin{array}{c}0.22 \\
(0.43)\end{array}$ & & \\
\hline Constant & $\begin{array}{c}-0.10^{* * * *} \\
(0.01)\end{array}$ & $\begin{array}{l}-0.08^{*} \\
(0.04)\end{array}$ & $\begin{array}{c}-0.10^{* * *} \\
(0.05)\end{array}$ & $\begin{array}{l}-0.22 \\
(0.23)\end{array}$ & $\begin{array}{l}-0.02 \\
(0.06)\end{array}$ & $\begin{array}{c}-0.14 * * \\
(0.06)\end{array}$ \\
\hline State Fixed Effects & $\mathrm{N}$ & $\mathrm{N}$ & $\mathrm{N}$ & $\mathrm{Y}$ & $\mathrm{N}$ & $\mathrm{N}$ \\
\hline$N$ & 728 & 728 & 728 & 728 & 728 & 728 \\
\hline$R^{2}$ & 0.01 & 0.02 & 0.02 & 0.11 & 0.01 & 0.10 \\
\hline
\end{tabular}




\section{REFERENCES}

Adelino, Manuel, Antoinette Schoar, and Felipe Severino, 2014, "Credit Supply and House Prices: Evidence from Mortgage Market Segmentation,” NBER Working Paper No. 17832 (Cambridge, Massachusetts: National Bureau of Economic Research).

Allen, Franklin, and Douglas Gale, 2004, "Competition and Financial Stability," Journal of Money, Credit and Banking,Vol. 36 (June), pp. 453-480.

Allen, Franklin, Elena Carletti, and Robert Marquez, 2011, "Credit Market Competition and Capital Regulation," Review of Financial Studies, Vol. 24 (April), pp. 983-1018.

Amel, Dean F., Arthur B. Kennickell, and Kevin B. Moore, 2008, "Banking Market Definition: Evidence from the Survey of Consumer Finances," Divisions of Research \& Statistics and Monetary Affairs, Federal Reserve Board, (Washington).

Beck, Thorsten, Asli Demirgüç-Kunt, and Ross Levine, 2006, "Bank Concentration, Competition, and Crises: First Results," Journal of Banking \& Finance, Vol. 30 (May), pp.1581-1603.

Becker, Bo, and Victoria Ivashina, 2015, "Reaching for Yield in the Bond Market," Journal of Finance, Vol. 70 (October), pp.1863-1901.

Berger, Allen N., and Timothy H. Hannan, 1989, "The Price-Concentration Relationship in Banking," The Review of Economics and Statistics, Vol. 71 (May), pp. 291-299.

Berger, Allen N., Rebecca S. Demsetz, and Philip E. Strahan, 1999, "The Consolidation of the Financial Services Industry: Causes, Consequences, and Implications for the Future," Journal of Banking \& Finance, Vol. 23 (February), pp. 135-194.

Bernanke, Ben S, 2007, The Subprime Mortgage Market, Board of Governors of the Federal Reserve System (US) Speech.

Boyd, John H., and Gianni De Niccolo, 2005, "The Theory of Bank Risk Taking and Competition Revisited," The Journal of Finance, Vol. 60 (June), pp. 1329-1343.

Brunnermeier, Markus K. and Christian Julliard, 2008, "Money Illusion and Housing Frenzies," Review of Financial Studies, Vol. 21 (January), pp. 135-180.

Brunnermeier, Markus K., and Yuliy Sannikov, 2014, "A Macroeconomic Model with a Financial Sector," The American Economic Review, Vol. 104 (February), pp. 379-421.

Cheng, Ing-Haw, Sahil Raina, and Wei Xiong, 2014, "Wall Street and the Housing Bubble," American Economic Review, Vol. 104 No. 9, pp. 2797-2829.

Chodorow-Reich, Gabriel, 2014, "The Employment Effects of Credit Market Disruptions:

Firm-level Evidence from the 2008-9 Financial Crisis," The Quarterly Journal of Economics, Vol. 129 (February), 1-59.

Claessens, Stijn, and Luc Laeven, 2004, "What Drives Bank Competition? Some International Evidence," Journal of Money, Credit and Banking, Vol. 36 (June ), pp. 563583.

Dagher, Jihad, and Ning Fu, 2017, "What Fuels the Boom Drives the Bust: Regulation and the Mortgage Crisis," The Economic Journal, Vol. 127 (June), pp. 996-1024.

Demyanyk, Yuliya, and Otto Van Hemert, 2011, "Understanding the Subprime Mortgage Crisis," Review of Financial Studies, Vol. 24 (June), pp. 1848-1880.

Dinerstein, Michael, Liran Einav, Jonathan Levin, and Neel Sundaresan, 2014, "Consumer Price Search and Platform Design in Internet Commerce," NBER Working Paper No. 
20415 (Cambridge, Massachusetts: National Bureau of Economic Research).

Favara, Giovanni, and Mariassunta Giannetti, 2014, "Mortgage Concentration, Foreclosures and House Prices," Unpublished manuscript.

Favara, Giovanni, and Jean Imbs, 2015, "Credit Supply and the Price of Housing," American Economic Review, Vol. 105 (March), pp. 958-92.

Foote, Christopher L., Kristopher Gerardi, and Paul S. Willen, 2008, "Negative Equity and Foreclosure: Theory and Evidence," Journal of Urban Economics, Vol. 64 (September), pp. 234-245.

Gan, Jie, 2004, "Banking Market Structure and Financial Stability: Evidence from the Texas Real Estate Crisis in the 1980s," Journal of Financial Economics, Vol. 73 (September), pp. 567-601.

Gan, Jie, 2007. "The Real Effects of Asset Market Bubbles: Loan-and Firm-level Evidence of a Lending Channel," Review of Financial Studies, Vol. 20 (November), pp. 1941-1973.

Gertler, Mark, and Simon Gilchrist, 1994, "Monetary Policy, Business Cycles and the Behavior of Small Manufacturing Firms," Quarterly Journal of Economics, Vol. 109 (May), pp. 309-340.

Glaeser, Edward L., Joseph Gyourko, and Albert Saiz, 2008, "Housing Supply and Housing Bubbles," Journal of Urban Economics, Vol. 64 No. 20, pp. 198-217.

Gurun, Umit G., Gregor Matvos, and Amit Seru, 2016, “Advertising Expensive Mortgages. Journal of Finance, Vol. 71 (October), pp. 2371-2416.

Hellmann, Thomas F., Kevin C. Murdock, and Joseph E. Stiglitz, 2000, "Liberalization, Moral Hazard in Banking, and Prudential Regulation: Are Capital Requirements Enough? American Economic Review, Vol. 90 (March), pp. 147-165.

Jensen, Michael C., and William H. Meckling, 1976, "Theory of the Firm: Managerial Behavior, Agency Costs and Ownership Structure," Journal of Financial Economics, Vol. 3 (October), pp. 305-360.

Jiménez, Gabriel, Jose A. Lopez, and Jesús Saurina, 2013, "How Does Competition Impact Bank Risk-taking?" Journal of Financial Stability, Vol. 9 (June), pp. 185-195.

Keeley, Michael C, 1990, "Deposit Insurance, Risk, and Market Power in Banking," The American Economic Review, Vol. 80 (December), pp. 1183-1200.

Keys, Benjamin J., Tanmoy Mukherjee, Amit Seru, and Vikrant Vig, 2009, "Financial Regulation and Securitization: Evidence from Subprime Loans," Journal of Monetary Economics, Vol. 56 (July), pp. 700-720.

Kiyotaki, Nobuhiro, and John Moore, 1997, "Credit Cycles," Journal of Political Economy, Vol. 105 (April), pp. 211-248.

Lacko, James M., and Janis K. Pappalardo, 2010, “The Failure and Promise of Mandated Consumer Mortgage Disclosures: Evidence from Qualitative Interviews and a Controlled Experiment with Mortgage Borrowers," The American Economic Review, Vol. 100 (May), pp. 516-521.

Landier, Augustin, David Sraer, and David Thesmar, 2015, "The Risk-shifting Hypothesis: Evidence from Subprime Originations," paper presented at the AFA 2012 Chicago Meetings (Chicago).

Loutskina, Elena, and Philip E. Strahan, 2009,"Securitization and the Declining Impact of Bank Finance on Loan Supply: Evidence from Mortgage Originations," The Journal of Finance, Vol. 64 (April), pp. 861-889. 
Mian, Atif, and Amir Sufi, 2009, "The Consequences of Mortgage Credit Expansion:

Evidence from the 2007 Mortgage Default Crisis," The Quarterly Journal of Economics 124 (November), pp.1449-1496.

Mian, Atif, and Amir Sufi, 2010, "The Great Recession: Lessons from Microeconomic Data," The American Economic Review, Vol. 100 (May), pp. 51-56.

Mian, Atif, and Amir Sufi, 2014, "What Explains the 2007-2009 Drop in Employment?

"Econometrica, Vol. 82 (November), pp. 13-43.

Palmer, Christopher, 2015, "Why Did so Many Subprime Borrowers Default During the Crisis: Loose Credit or Plummeting Prices?" Unpublished manuscript.

Peek, Joe, and Eric S. Rosengren, 1997, "The International Transmission of Financial Shocks: The Case of Japan," The American Economic Review, Vol. 87 (September), pp. 495505.

Peek, Joe, and Eric S. Rosengren, 2000, “Collateral Damage: Effects of the Japanese Bank Crisis on Real Activity in the United States," American Economic Review, Vol. 90 (March), pp. 30-45.

Petersen, Michael A., and Raghuram Rajan G, 1995, "The Effect of Credit Market Competition on Lending Relationships," The Quarterly Journal of Economics, Vol. 110 (May), pp. 407-443.

Saiz, Albert, 2010, “The Geographic Determinants of Housing Supply," The Quarterly Journal of Economics, Vol. 123 (August) pp. 1253-1296.

Schaeck, Klaus, Martin Čihák, 2014, "Competition, Efficiency, and Stability in Banking," Financial Management, Vol. 43 (Spring), pp. 215-241.

Schaeck, Klaus, Martin Čihák, and Simon Wolfe, 2009, “Are Competitive Banking Systems More Stable?" Journal of Money, Credit, and Banking, Vol. 41 (June), pp. 711-734.

Scharfstein, David, and Adi Sunderam, 2016, "Market Power in Mortgage Lending and the Transmission of Monetary Policy," Unpublished manuscript. 